ISSN 2282-8168

\title{
CEFIN Working Papers
}

No 72

Why choosing dominated personal pension plans: sales force and financial literacy effects

\author{
by Giuseppe Marotta
}

July 2018 


\title{
Why choosing dominated personal pension plans: sales force and financial literacy effects
}

\author{
Giuseppe Marotta*
}

This version: 22 July 2018

\begin{abstract}
We investigate the puzzle of choices of dominated personal pension instruments in Italy, with insurers' products (PIPs) much more subscribed than shares of open pension funds offered by banks (FPAs). We find evidence, using the three waves of Bank of Italy's Survey of Household Income and Wealth (SHIW) between 2010 and 2014, of a sales force effect deriving from a network of post offices and independent financial advisors associated with insurance companies much more widespread than bank branches. We document that financial literacy has a significant dampening effect on the supply push factor only for PIPs, and especially for the subset with voluntary matching employers' contributions. The effect is detected mostly in the 2014 SHIW wave, the one fully affected by the implementation of the pension system reform legislated in December 2011.
\end{abstract}

Keywords: Pension system reform; Financial literacy; Retail financial products distribution; Italy

JEL Classification: D91; E21; G11; H55

\footnotetext{
*University of Modena and Reggio Emilia and Cefin giuseppe.marotta@unimore.it
} 


\section{Why choosing dominated personal pension plans: sales force and financial literacy effects}

\section{Giuseppe Marotta}

\section{Introduction}

The Italian Pension Supervisory Authority (COVIP) documents a long standing choice of dominated financial products by Italian workers. Personal pension plans offered only by insurance companies ("new" Personal Investment Plans, PIPs) are much more widely subscribed than shares in open pension funds (FPAs), sold by insurers as well as by banks, in spite of an historical track of lower realized net returns and higher perspective costs.

This paper is the first, to our knowledge, to probe into the determinants of subscriptions of PIPs and FPAs, and whether they changed owing to the consequences of the December 2011 state pension system reform on the expected total pension income. To this end we use the three biennial waves of Bank of Italy's Survey of Household Income and Wealth (SHIW) between 2010 and 2014. The time span encompasses a macroeconomic scenario of recession and worsening labour market (a real GDP in 2014 more than 2\% below the 2009 level and a loss of almost one million jobs), owing to the euro sovereign risk crisis that led, in order to correct a fundamental source of public debt unsustainability, to a major overhaul of the public pension system (Fornero reform), with only a minor change in the tax rate on financial returns of all pension funds.

The main findings are three.

First, we detect a strong heterogeneity in the statistical significance of estimates across the waves, a result that lends support to the hypothesis that the 2011 reform that raised retirement age and seniority requirements has reinforced the explanatory power of financial determinants in personal plan subscription choices.

Second, we find that the most robust and statistically significant estimates refer to the proxies for supply side determinants, whereby the comparative advantage for subscriptions in PIPs rather than in FPAs is negatively and significantly correlated with the size of the city where employed household heads live. Our tentative interpretation points to a sales force effect, because of the reduced local availability of bank branches, which can offer both FPAs and 
PIPs, compared with the independent financial advisors associated with insurance companies, who have reward incentives to push investors toward PIPs, as well as with the countrywide network of post offices, which sell only in-house PIPs.

Third, we find that the indicator for the highest financial literacy level is statistically significant, with the expected dampening effect on the supply push toward PIPs, but only in the 2014 wave, the one affected by the full implementation of the pension reform legislated at the end of 2011, and especially when investigating the determinants of the subscription rate for the subset of PIPs with matching employers' contributions. A similar outcome is obtained however also when using other indicators for lower levels of financial literacy (two instead of all correct answers to the "Big Three" questions).

This paper contributes to several literatures.

A first contribution is to the growing literature on consumers' investment mistakes (starting from Campbell 2006; see also Hastings et al. 2013, 2017; Guiso and Sodini 2013; Iscenko 2018, and the references therein). Our investigation centres on the possible changes, because the 2011 pension system reform should have raised workers' financial awareness on the issue, in the explanatory power of the same set of determinants on the demand and supply sides in reduced form specifications for subscription rates of the two personal pension plans, one widely known to be dominated by the other. The pension reform event, widely known given the widespread media coverage and the political controversies that ensued ${ }^{1}$, calls for a research framework different from the experimental study by Finseraas and Jakobsson (2014) that detected effects on retirement plans when considering a different exposure to information on a 2011 pension reform in Norway between a treatment and a control group.

A second contribution is to the literature concerning the role of supply factors in the choices of dominated instruments, focusing on an instance of the sales force effect, namely the local availability of point of sales for the two personal pension plans. Related recent papers are Gurun et al. (2016), for the case of expensive mortgages linked to the intensity of local advertising in the US, and Hastings et al. (2017), for the case of social security privatization in Mexico.

A third contribution is to the literature on financial literacy concerning different measures of this elusive concept and, what is more, on the financial outcomes they can bring

\footnotetext{
${ }^{1}$ In a survey referring to would-be retirees aged at least 55 years, less than one tenth of the respondents answer to have never heard of the reform, with over 40 per cent claiming to be aware of it and understanding its implications (Fornero et al. 2018).
} 
about, as well as on the policy implications on the cost effectiveness of education efforts aimed at increasing financial literacy (Lusardi and Mitchell 2014 and references therein; Hastings et al. 2013, 2017).

The remainder of the paper is organized as follows. Section 2 provides an overview of the Italian pension system and spells out the two main research questions. Section 3 presents an explanatory analysis based on descriptive statistics on self-reported participation in private pension plans and on the association with financial literacy levels. Section 4 describes the empirical specifications and methodology that we use in the econometric investigation. Section 5 presents the empirical findings results and their interpretation. Section 6 concludes and draws the main policy implications.

\section{An overview of the Italian pension system and research questions}

The Italian public pension system belongs to the notional defined contribution type, whereby the expected pension depends on the contributions accrued during the working period and on the notional rate of return tied to the GDP growth rate. The later the youth starts working, the more discontinued the work career, the lower the economy's growth also because of the ageing, the more inadequate is the expected pension to guarantee a decent way of life in retirement. These features motivate the grim perspectives for the Italian youth, as enshrined in the governmental projections that take into account demographic trends and public finance sustainability issues. The Fornero reform accelerated toward a generalized notional contribution system, ending the slow phasing in of this system. Indeed, also workers with a career of at least eighteen years in 1995 who had been allowed to stay in the pre-existing defined benefit system, were now inserted for the remaining working career in the defined contribution regime. The curtailment of the expected accrued capital at retirement was bound to affect the choices for personal pension plans, with the aim to offset, at least partially, the ensuing loss.

A three-pillar tax-incentived defined contribution private pension system supplements the public pension system. The first pillar consists of (non mandatory) occupational schemes (Fondi pensioni chiusi or FPNs) for dependent workers covered by collective agreements between trade unions and employers that determine also employers' compulsory matching contributions. The second and the third pillars are two (voluntary) types of personal plans, for dependent workers as well as for self-employed and non-employed: a) Fondi pensione aperti (FPAs), created and managed by banks and insurance companies and open to both individual 
and collective subscriptions; b) since 2007, "new" Piani Individuali Pensionistici (from now on, PIPs), that is policies sold exclusively by insurance companies and that can be subscribed only individually, marketed also by banks, post offices and independent financial advisors ${ }^{2}$. Employers can voluntarily provide matching contributions for both FPAs and PIPs. Two other components, that are a legacy and, with some exceptions, closed to new membership, are "old" PIPs and pre-existing (i.e. existing before the 1992-95 overhaul of the pension system) firmbased occupational pension funds. The focus of this paper is on the second and third pillar of the private pension system. However, SHIW data do not allow to identify old and new PIPs and provide data on all private pension funds with employers' matching contributions that do not distinguish between FPNs and FPAs.

FPAs offer different sub-funds, ranging from low-risk investment style to a riskier one (i.e. all-share). PIPs' subscribers, can choose traditional life insurance products (Ramo I), invested almost entirely in (domestic) public bonds, or a portfolio of unit-linked investment plans, with different risk profiles, managed by the same company or by another one (Ramo III); a combination of both choices is also available ${ }^{3}$. A noticeable difference, on transparency ground for potential subscribers, is that FPAs and unit-linked based PIPs adopt a market price valuation and there is no guarantee on the sum of nominal contributions, gross of the management costs; PIPs that replicate traditional life insurance products are instead valued at historical cost and provide a guarantee on the cumulated contributions.

Table 1 reports the subscriptions to the private pension system starting from 2007, when PIPs were introduced following a law passed in 2005. A remarkable fact is the increase of PIPs between 2007 and 2017, almost twice the combined increase of the subscriptions to FPNs and FPAs, about 800,000 and 600,000 respectively ${ }^{4}$. The finding is not materially affected by the possible overestimation in PIPs data, since the COVIP statistics until 2015 were unable to properly handle multiple memberships (i.e. a person could subscribe to several personal plans).

\section{TABLE 1 APPROXIMATELY HERE}

\footnotetext{
${ }^{2}$ PIPs differ from life insurance products mainly because of age pension eligibility requirements.

${ }^{3}$ Subscriptions and contributions in traditional life insurance policies amount to more than 70 per cent of total PIPs (COVIP 2015).

${ }^{4}$ The data are gross of the subscriptions with missing contributions, at all or during the year. The proportion is sizable and increasing during the five years considered: overall, almost one fourth, rising to over 30 per cent for PIPs and even more for FPAs, hitting mostly self-employed who can rely exclusively on own contributions (COVIP 2011, 2013, 2015).
} 
In fact, according to the new COVIP information system, implemented provisionally since 2015 and fully operative since 2016, the effective membership of the private pension system at end-2015 - the year closer to the last SHIW wave used in this paper - amounted to 6,716 million (included 434,000 in old PIPs), with a reduction of almost $8 \%$ relative to the grand total of 7,235 million. The subscribers to only one sub-fund among FPNs, FPAs and PIPs were 5,744 million. The remaining 1,108 "subscriptions" referred to 538,000 individuals, mostly with double membership (only 6,000 individuals had triple or quadruple membership). Almost two thirds involved PIPs: they were taken by 172,000 enrollees in FPNs, 78,000 in FPAs, 90,000 in other PIPs (COVIP 2017).

Individual subscriptions of self-employed and not employed, negligible in FPNs, accounted for almost a half in FPAs at end-2016 (COVIP 2017). The share of collective subscriptions to FPAs in 2015 was instead equal to $18 \%$; only $20 \%$ of the investment in PIPs were funded through the accruals to TFR (capitalized deferred wage $)^{5}$ and optional private employers' contributions (COVIP 2016).

The "revealed" preferences between PIPs and FPAs are a "financial mistake" (Campbell 2006), given two widely known fundamentals. First, PIPs' averaged net returns since 2008 are consistently lower than FPAs' ones (Tables 2 and A.1). Second, the Synthetic Cost Indicator (SCI), as a percent of the accrued capital, that takes into account the expected averaged main recurring costs for subscribers (initial membership, annual administration and management fees, transfer of the individual position across sub-funds) over different investment periods, as estimated by COVIP (hence, public knowledge), is consistently higher for PIPs (Table 3).

These stylized facts raise two research questions.

First research question. Do supply factors overhaul the demand factors, which would suggest to choose FPAs instead of PIPs, given the lower prospective costs and the higher realized net rate of returns even for all unit-linked based PIPs? A likely suspect are higher monetary incentives earned by financial advisers when nudging investors towards a subscription to a PIP rather than a FPA. Anecdotal evidence supports the claim that the mechanism is at work within banking groups having commercial agreements with independent

\footnotetext{
${ }^{5}$ The annual return rate is determined by law as to 1.5 per cent plus $3 / 4$ of the inflation rate. A private sector employee who decides not to subscribe to the eligible occupational pension scheme and to invest instead the TFR accruals into a PIP or a FPA gives up the right to get the compulsory matching employer's contribution; the employer can however voluntarily agree for matching contributions.
} 
or in house insurance companies. The pension supervisory authority itself consistently hints that the huge increase in PIPs membership in comparison with the alternative choice could be explained by aggressive selling policies of financial advisers, because the variable component of their compensation is linked to the fee-generating PIPs subscriptions (COVIP 2011 55; 2015, $23 ; 2016,43)$.

Owing to the lack of hard data on these candidate supply push factors we try to detect their effects with a proxy - the size of the city where HHS live - as an indicator of the comparatively different availability of points of contacts - for advisory and subscriptions. A possible motivation for dominated choices could in fact be that from investors are nudged towards PIPs by the financial agents they are acquainted with in local markets.

In the 2007-2014 period, the industry of private pension funds, except for PIPs, has undergone an, indeed overdue, process of concentration, in order to exploit economies of scale for assets under management. FPNs and FPAs have shrunk by 4 and 2, respectively; PIPs have instead increased by $6^{6}$. The likely effects of these divergent trends are greater economies of scope, that can enhance the marketing potential, though with a widening of the already significant cost differential for PIPs ${ }^{7}$.

PIPs can be marketed in any financial outlet (bank branches, post offices, independent financial advisers); insurers are also licensed to sell FPAs. At end-2017, out of 35 insurance companies offering PIPs, 21 were selling also FPAs. Bank branches, which advertise also personal pension plans, are however less widespread in smaller cities compared to independent financial promoters of insurance products and, above all, post offices. As of 2017, in fact, the market leader for PIPs is Poste Vita Group, a subsidiary of the state-controlled Poste Italiane group, with a stock of 943,000 PIPs (more than three times the 2010 figure) and a market share of one third. Poste Italiane's 13,000 post offices are present in almost any Italian city (owing to the universal postal service mandate $)^{8}$, and unlike bank branches are open also Saturday

\footnotetext{
${ }^{6}$ At end-2017, FPNs have fallen by 3, to 35; FPAs by 7, to 43; PIPs by 1 to 77 (of which 35 are closed to new subscriptions); COVIP (2018).

${ }^{7}$ Indeed, Italy is the country with the highest spread in recurrent costs (i.e. management fee of the asset manager) among distributors for each product by EU states for products with capital guarantee (life insurance and pension products) and ranks third and fifth, respectively, for the spreads in capital pension guaranteed and mutual funds pension products (EC 2018, Table 6). Italy is also the country with the largest spread for one-off fees in life insurance products without capital guarantee (EC 2018, Table 7).

${ }^{8}$ As a way of comparison, the two largest banking groups, Intesa and Unicredit, have respectively about 4,600 and 3,100 branches.
} 
morning. Subscribers of PIPs sold by Poste Vita have their pensions credited in their postal deposits (Poste Italiane 2018). Worthy of note is another ex ante comparative advantage for Poste Italiane when contacting a potential subscriber. Postal deposits are guaranteed in full by the state, whereas bank deposits are insured up to 100,000 euro per depositor per bank by the banks' national deposit insurance scheme. Furthermore, the state control of the Poste Italiane could raise expectations, on moral hazard grounds, that the traditional life insurance policies subset of PIPs sold by the controlled Poste Vita are less risky in comparison with other insurance companies. These facts can help to rationalize why, in a survey on the perceptions and information on the 2011 pension reform among would-be retirees aged 55 years and over, banks are considered more trustworthy as a source of financial advice by a factor of more than two and four, respectively, compared with independent financial advisers and insurance (Fornero et al. 2018). On the one hand, these evaluations can be ineffective in terms of outcomes because of the constraint of geographical market structure heterogeneity. On the other hand, the survey does not consider explicitly the state controlled Poste Italiane.

The geographical market structure for FPAs and PIPs reminds of a recent study on the Mexican private account Social Security system that documents that many participants invest their account balances with dominated financial providers, which charge high fees not offset by higher returns but invest heavily in sales force and advertising, non-price attributes that substitute for competition on price (Hastings et al. 2017).

\section{TABLES 2-3 APPROXIMATELY HERE}

Second research question. Do financially literate potential subscribers choose more carefully looking through sellers' advices? As OECD $(2016,132)$ puts it, "Members of DC plans [...] should be aware that they are directly charged a fee for administration and asset management services. These costs can have a material negative impact on future retirement income. Individuals should keep costs into account when estimating their retirement income needs but complicated fee structures may make comparisons across different plans difficult".

A higher level of financial literacy should help raise the awareness about the supply push factors towards PIPs rather than FPAs, the more so when the Fornero reform is likely to have enhanced the attractiveness of private pensions. Potential subscribers should have been able - the better so if financially literate - to focus their minds on how to offset the perspective reduction in the substitution rate of the public pension system, against a backdrop of a more 
acute perception of public debt sustainability risks. After all, this was the main driver of the reform, aimed at restoring markets' confidence in the public debt of the third largest Eurozone country.

We answer the research questions relying mostly on the three waves, from 2010 to 2014, of the Bank of Italy's biennial survey on household income and wealth (SHIW), that include an identical questionnaire on private pension choices. The time span fits the research agenda because, against the backdrop of macroeconomic recession context, it allows to investigate on the possible, though delayed, effects of one major, unexpected but widely known once legislated, innovation in the pension system, whereas the only change for the private pension system was a minor rise in the substitute tax rate on financial returns ${ }^{9}$. Only the 2010 SHIW wave, that includes a special module, can instead be used to compute indicators on financial literacy levels.

\section{Personal pension choices and financial literacy in the 2010 SHIW: an exploratory analysis}

The Section is organized as follows: a) an overview of SHIW; b) descriptive statistics on self-reported participation in private pension plans, in order to assess how representative is the survey; c) an exploratory analysis on the association between financial literacy levels computed for the 2010 wave and subscription rates in private pension plans.

\section{a) Overview of SHIW.}

Bank of Italy's SHIW is a biennial survey on income and wealth with about 8,000 household heads (HHs), i.e. the component who takes the main decisions on household's finances. Each survey, besides a fixed template, has modules that may or may not be replicated in the next wave. In our case, only the three waves from 2010 to 2014 have a module on the subscription to private pension, with identical wording (see Appendix). A module on financial literacy is present instead only in the 2010 SHIW, and this is the reason why, being interested in investigating the links between subscription rates in pension plans and financial literacy, we build a balanced panel (BP) of 2320 HHs 25 to 65 years old.

\footnotetext{
${ }^{9}$ The substitute tax rate was further raised retrospectively from 11.5 to $20 \%$ beginning first January 2014 , in the Financial Law for 2015, approved at end 2014. The survey data for the 2014 SHIW wave, collected during the year, before the unexpected innovation, should not therefore be affected.
} 
Wealthier HHs, who are likely to be more interested into - and financially capable of - subscribing personal pension plans ${ }^{10}$, are also the ones more affected by under- and misreporting on (net of taxes) income and current value of wealth, real and financial (including pension funds and life insurance), as exhaustively documented by Baffigi et al. (2016, Section 4). In this paper we deal with these data issues as follows. First, we adjust household income ${ }^{11}$ for the number of its components, using the OECD equivalence weights; second, we split the resulting equivalent income and financial assets by deciles ${ }^{12}$; third, as an indicator of housing wealth we use a binary variable ownership/no ownership of the main home ${ }^{13}$; fourth, we take into account debt with a binary variable on whether a $\mathrm{HH}$ is a mortgagee or not. The drawback of these choices, with all explanatory variables in binary or categorical format, except for age, is to shrink the variation in micro data, already low over a time span of five years, and to have high correlation among the indicators of equivalent income and financial assets. With respect to this last issue, to reduce collinearity, we drop financial assets as an explanatory variable.

\section{b) Private pension plans participation.}

The averaged subscription rates computed out of HHs' answers of the three waves for the balanced panel, adjusted for sample weights, reveal sizable differences within the SHIW data and compared with COVIP data as well (Table 4).

\section{TABLE 4 APPROXIMATELY HERE}

The most puzzling finding is the very low subscription rate to FPNs, given the grand total of subscription rate to any private pension plan, included also old PIPs and pre-existing occupational pension funds ${ }^{14}$. The combined averaged subscription rates to all pension plans in each wave $(24.8,26.5$ and 23.6 per cent) is roughly similar to the grand total only if the "real" FPNs subscribers are the ones acknowledging employers' matching contributions, an assumption that disregards that they include also the voluntary contributions for FPAs and

\footnotetext{
${ }^{10}$ One of the fiscal incentives is the income tax break up to 5,165 euros.

${ }^{11}$ Nominal income is not adjusted given the low inflation rates experienced in the period 2010-14.

12 A different choice was adopted in a study on the demand of life insurance by Italian households, financial inclusion, and financial literacy, where income and wealth are entered as log of current values drawn from the 2004-2012 SHIW panel dataset (Luciano et al. 2016).

${ }^{13}$ Though even the number of dwellings - main residence and not - is sizably under-reported, the measurement issue should be plausibly less relevant when considering the main home (Baffigi et al. 2016, 81-83).

${ }^{14}$ SHIW data do not allow to take into account how many subscribers have not paid contributions, in the year or at all. According to COVIP data, these subscribers amount to at least one fifth, and are more concentrated on personal pension plans, and especially among self-employed, with a proportion of almost one third (for data up to 2014 see COVIP 2015).
} 
PIPs. The underestimation of average participation rates in surveys may be due to several reasons, including respondents' tendency to mis-report financial decisions (Gustman et al. 2008). In the case of Italy, Cappelletti and Guazzarotti (2010) documented a significantly lower participation rate in the private pension system in the 2008 SHIW, compared to COVIP data, possibly because of under-reporting and low sampling of workers in sectors with aboveaverage participation rates, such as at large firms.

A second puzzle in the data is the rather erratic dynamics of SHIW statistics on participation rates, across waves, when compared with the steady upward trend in the COVIP data in Table 1, mostly determined by the increase in PIPs.

These descriptive statistics suggest therefore caution in drawing policy implications from the results of the empirical investigation based on individual data, unadjusted for sample weights, though SHIW it is the best database available.

c) Financial literacy and personal pension plans subscriptions.

Financial literacy needs vary in relation to different types of retirement saving. As underlined in $\operatorname{OECD}(2016,128)$, decision-making about retirement is likely to be more difficult and require better financial literacy when making choices on personal pension plans. Indeed, a more diversified portfolio of investment alternatives requires greater financial skills when compared to the occupational plans, which have a narrower range of options as for the choices of the provider and of the plan. Moreover, lower amounts of assets under management in personal occupational plans imply that, for a given target of the accrued capital at retirement, subscribers have to contribute more on their own, in order to offset higher costs from reduced economies of scale and/or to accept riskier investment profiles.

The questions that operationalize the enquiries on the financial literacy that have come to be known as the "Big Three" - interest compounding, inflation and real interest rate, risk diversification - (e.g. Lusardi and Mitchell 2011a, Klapper et al. 2016) are unlikely to fit the required competencies for retirement investment choices, as stressed by the OECD. In addition, it is an open issue how to map into a meaningful ranking score the number of correct answers to fairly different questions (Hung et al. 2009), thus making it hard to detect financial literacy effects on pension choices. Finally, a necessary condition for financial literacy to turn into financial capability to implement "optimal" investment choices is that the potential subscriber earns enough to save. 
Against this backdrop we exploit the 2010 SHIW, that has a module with three questions on financial literacy, for an exploratory analysis of the characteristics of subscribers to private pension plans. Though the main focus is on personal plans, we consider also the choice to subscribe to any type of private pension plans, because being not mandatory they imply an active choice.

The first question on financial literacy combines concepts of mortgages with fixed and variable interest rate, and of variable or constant mortgage instalments; a second question is centred on nominal interest rate and inflation; a third one is on risk diversification (see Appendix for the exact wording). As it is common in international comparisons on financial literacy (Lusardi and Mitchell 2014), around one third of HHs answers correctly to all three questions; the risk diversification issue is the least understood.

As expected, the distribution of correct answers among subscribers of private pension plans is tilted towards a higher score, but there is no strong association with the different levels of financial literacy: the statistics on the association with a correct answer on risk diversification are similar to the ones referring to at least two correct answers (Table 5).

\section{TABLES 5-6 APPROXIMATELY HERE}

Unsurprisingly, financial literacy should show up also when investigating its association with an indicator of participation in the market of risky financial instruments, namely ownership of shares and mutual funds, notwithstanding the well-known underreporting issue. Again, a correct answer on the question on risk diversification shows up as equivalent to other indicators for at least two correct answers (Table 6). The association between holding risky assets and subscription rates to private pension plans confirms qualitatively the findings of Table 5.

Finally, in order to take into account that financial constrains could inhibit the financially literate from implementing proper investment choices, we exploit a question, present in all three waves, on whether the HH has been able to save in the reference year ${ }^{15}$. As expected, positive savings are associated with higher financial literacy levels (Table 7) and higher subscription rates in pension plans as well (Table 8).

\footnotetext{
${ }^{15}$ We prefer this subjective information to the alternative of computing saving as income minus consumption expenditure, because the under- and mis-reporting in their nominal values, which affect especially the second variable, yields overestimated savings (Baffigi et al. 2016).
} 


\section{TABLES 7-8 APPROXIMATELY HERE}

\section{The econometric investigation framework}

The econometric investigation has to cope with the reduced variation and change, if ever, of the categorical variables owing to the short time span. We rely therefore on single wave cross-sections estimates and, when probing into financial literacy, on reduced samples drawn from a balanced panel, because a questionnaire is available only for the 2010 wave.

The baseline reduced form specification of the cross-section equations with controls for the usual demographic characteristics focuses on assessing, first, the explanatory role on the subscription rate in five types of personal pension plans of 25-65 years old employed HHs of financial explanatory variables on the demand side as well as of suppliers' local availability indicators. Worthy of note is that the much higher proportion of PIP subscriptions over all private pension plans (PENS) in the SHIW individual data (around 47\%), compared to the reference universe (about one third in the 2015 COVIP revised data, net of multiple subscriptions), should result in similar estimated coefficients in the respective equations, though with magnified effects when referring to PIPs rather than to PENS.

The baseline specification for the i-th $\mathrm{HH}$ is:

$S_{i}=D_{i}+Y W_{i}+F S_{i}+G S_{i}$

where:

$S=$ binary variable for a $\mathrm{HH}$ being subscribed to any private pension plan (PENS), PIPS as a whole and the subsets with and without matching voluntary employers' contributions (PIPCs and PIPNCs), open pension plan $(F P A s)^{16}$;

$D=$ binary variables for demographic characteristics (female, upper secondary degree, university degree, single, widow(er), private employee, public employee, small firm with 5-49 workers, medium firm with 50-99 workers, big firm with 100 workers and over, resident in the North, resident in the Centre), except for the continuous variables age and age squared;

\footnotetext{
${ }^{16}$ In principle, there could be a potential sample selection issue, because only a subscriber to any private pension plan could also be a PIP or a FPA subscriber. As remarked, however, the data do not allow to recover the gran total as the sum of the three subsets, namely FPNs, PIPs, and FPAs.
} 
$Y W=$ binary variables for second to tenth equivalent income deciles income, home ownership and mortgagee status;

$F S$ = financial strength binary variables (positive saving, risky asset ownership);

$G S=$ binary variables proxying suppliers' local availability (medium city, with 20,000 to 40,000 inhabitants; large city, with 40,000 to 500,000; big city, with 500,000 and over).

The reference characteristics of the omitted $\mathrm{HH}$ are male, up to lower secondary degree, married, self-employed, micro firm with 1-4 workers, resident in the South and Inlands, first decile of equivalent income, no home owner, no mortgage, no saving, no risky asset owner, small city with less than 20,000 inhabitants.

The expected signs for most demographic characteristics and income and home ownership are the ones usually found in the literature. The sign for the status of mortgagee is instead uncertain, because being already a bank customer could ease, from both demand and supply sides, the access to another bank product, namely an FPA. The financial strength variables we are more interested in, also because of direct and reverse linkages with financial literacy, are expected to be positively signed.

As for the proxies on local suppliers' availability, the city size categorical variables should be associated with different signs and statistical significance between PIPs (negative and significant) and FPAs (uncertain sign and not significant). The effects could be further enhanced in the case of PIPCs, because the voluntary employer's contribution could make them more attractive for sellers, compared with PIPNCs.

In order to take into account the pension system environments before (2010), at the inception of (2012), and after (2014) the full implementation of the Fornero reform, we are interested in comparing estimates across waves. We expect that the role of the indicators of financial strength should increase between 2012 and 2014 as (wealthier) HHs react to the reform.

Against the backdrop of five baseline estimation results for the cross section in each SHIW wave, we investigate subsequently whether different levels of financial literacy have an own statistically significant effect. We add to the baseline specification above as a regressor a binary indicator equal to 1 when all three answers are correct, 0 otherwise. Financially literate investors should be more careful in acting on sellers' claims, and therefore the expected sign is negative. We explore also whether there is evidence of significant differences when considering various levels of financial literacy as well as interactions between financial literacy levels and suppliers' local availability, because smaller cities could in principle be a social environment less favourable to nurture financial literacy. 
Owing to data availability, the estimates refer to the cross sections extracted from the balanced panel, under the assumption that the level of financial literacy in the 2010 SHIW of each HH 25-65 years old surviving in the successive waves remains the same.

Two remarks on the estimation samples are worthy of note.

First, by construction, the samples are modified across waves because HHs aged 65+ exit but there are no entries of younger ones. The changing composition effect therefore leads to increasing average age and consequently, as suggested by a life-cycle framework, to higher average income and wealth. The averages, across waves, for the reduced samples, compared with the ones for the full samples, do bear out the easily foreseeable outcomes for the percentage composition: lower and stable status of single, slow increase in university degree, increasing concentration in the tenth income decile (computed including also pensioners and other not employed people), higher and increasing home ownership (Tables A.2-3). The dynamics is quite different in the two datasets also for other less obviously trends: reduced incidence of residence in the Northern region, decreasing share of public employment, not completely offset by the trend in private employment, falling share of self-reported savers, opposite trends for mortgagees.

Second, because of the no entries in the reduced sample, also the subscription rates to any private pension plan show almost no dynamics. This is in contrast with the declining trend in the full sample, except for FPAs, a trend that, as already remarked, does not match the aggregate COVIP data, most especially for PIPs.

We run both linear probability models (LPM) and probit models. Being the results almost identical for size, sign and statistical significance of the regressors, we report only the LPM estimates, more robust to collinearity deriving from the low variation in micro data, and the average marginal effects computed out of the probit estimates for the explanatory variables we are more interested in (gender, financial strength, suppliers' local availability).

\section{Empirical findings and discussion}

Full sample cross sections

PENS. The main results of the LPM estimates broadly confirm the expected effects for the explanatory variables, with an overall different pattern between 2012 and 2014 (Table 9). 


\section{TABLE 9 APPROXIMATELY HERE}

i. Income and housing wealth variables have the expected sign and statistical significance in each cross section, with some intriguing variability across waves. The positive and significant differential effect of higher income deciles, as made possible by the saving capability and by the ability to exploit the incentive of the fiscal deductibility of own contributions, shrinks: it is detected starting from the seventh decile in the 2014 wave instead of the fifth one in 2010 and 2012, with an overall loss of significance. Home ownership is (weakly) significant only in 2014. On the contrary, even demographic characteristics, such as being single, being a widow(er) and living in the Northern become insignificant in the 2014 wave. A special case of demographic characteristics is the different size of firms, with a positive higher differential effect the larger the firm. The categorical variables could proxy the trade unions role as sponsors of occupational plans (especially for PENS), as well as capture the "efficiency wage" effect of larger firms willing to offer comprehensive compensation packages that include voluntary employers' contributions to personal plans (especially for FPAs and PIPCs).

ii. Financial strength indicators are always jointly statistically significant. The saving coefficient has the expected positive sign and, compared with 2010 and especially with 2012, increases in absolute value and significance in 2014.

iii. Sellers' local availability variables are always negative and highly significant, except for the 2012 wave. An interesting difference with respect to the 2010 wave is the pattern of increasing absolute value in the 2014 wave for the coefficients of two upper city size categories.

iv. Overall, the estimates for the 2014 wave following the full implementation of the Fornero reform support the claim that expected reactions in the pension choices towards private pension plans are detectable, especially for financially stronger households; the variability in the reactions across most other demographic and income characteristics compared with the reference ones is instead reduced.

PIPs. The findings on PENS show up more sharply in the case of PIPs, that as previously remarked account for about a half of all pension plans on unadjusted data for sample weights.

Compared with the 2012 wave, the 2014 one yields even more clearly that the subscription rate is mainly associated with indicators of financial strength, as well as of home 
ownership, whereas income variables differential effects almost disappear (Table 10). When compared with the case of PENS, the estimated coefficients for the sellers' local availability indicators, always negatively signed, are more statistically significant (even in 2012) and larger in absolute values, especially for the two upper city size categories.

\section{TABLES 10 -12 APPROXIMATELY HERE}

PIPCs, PIPNCs. When considering PIPs with and without voluntary employees' contributions, what explains most the differences between the 2012 and 2014 waves is that subscribing PIPCs turns out to be strongly associated with sellers' local availability; as for the indicators of financial strength, saving is strongly significant only for PIPCs whereas ownership of risky asset only for PIPNCs (Table 11). The changing role of financial strength and sellers' local availability across waves is revealed also by the two joint exclusion tests: the null for the city size categories is not rejected in the 2010 wave for PIPNCs and in the 2012 wave for PIPCs; both nulls are strongly rejected in the 2014 wave.

FPAs. As expected, most coefficient estimates for sellers' local availability proxies are statistically insignificant; the exception, at a $10 \%$ level of confidence, is the coefficient for the big city categorical variable in the 2012 wave (Table 12). It is worthy of note that only for FPAs, in the 2014 wave, the state of being a mortgagee is (weakly) significant and positively signed, a finding that hints at an enhancing effect of being already a bank customer for the subscription of products, FPAs, offered also by banks.

To sum up, the average marginal effects, computed using the probit estimates of the baseline specifications for 45 years old HHs (a typical worker's prime age peak) provide a synopsis of the change in probability when each dummy variable for the financial strength and supply indicators takes a value of one, instead of zero (Table 13. The overall picture is of a 2014 wave that, in comparison with the 2012 one, has a larger set of highly significant average marginal effects, positively signed for the financial strength variables and negatively for the suppliers' local availability indicators, except for FPAs.

TABLE 13 APPROXIMATELY HERE

Financial literacy in cross sections out of the balanced panel 
Are the results, especially for suppliers' local availability indicators, robust to the introduction of controls for financial literacy levels? We probe the issue adding to the baseline specifications a binary indicator (finlit_3) equal to one for HHs who in the 2010 SHIW answered correctly to all three questions, and zero otherwise. The same indicator is imputed to the surviving (i.e. not exiting, because of age or becoming not employed) households in the 2012 and 2014 waves of the balanced panel.

i. Given the different composition of the reduced samples, compared with the full ones, it is not surprising the loss of significance for many explanatory variables, especially the income deciles as well as the (joint) financial strength variables. It is therefore even more interesting to underline the robustness of the estimates for sellers' local availability indicators (Tables 14-17).

One motivation for the less relevant role of financial strength variables is that finlit_3 is in general weakly significant and/or could be highly collinear in particular with the risky asset ownership (see Table 5). An interesting result is that the finlit_3 coefficient, never significant in the 2010, is significant in the PIPCs regression in 2012 and in the PIPs and PIPNCs ones in 2014, and negatively signed. Our interpretation is that these findings lend support to the claim that financially literate investors, acquainted with the effects of the Fornero reform, react with a progressively more careful choice of personal plans, thus reducing the nudging effects of PIPs suppliers. Indeed, when we enter the financial literacy indicator interacted with the city size indicators, we get significant estimates even where finlit_3 alone was not (PENS in 2012 and 2014, PIPs in 2012, PIPCs in 2010 and 2014).

The average marginal effects of finlit_3, also interacted with city size indicators, are overall similar to the ones obtained for the full sample. A remarkable difference is the negative marginal effect in the PIPCs case, which is also increasingly larger in absolute value and statistical significance across waves (Table 18).

\section{TABLES 14-17 APPROXIMATELY HERE}

ii. These results raise some doubts on a strategy aimed at a higher rather than simply a basic financial literacy. Some hints can be inferred comparing the statistically significant average marginal effects obtained replacing finlit_3 with seven alternative indicators, computed according to whether the correct answers to the three questions on the 2010 SHIW 
range from one to at least two ${ }^{17}$ (for descriptive statistics see Table A.3). Year, sign and significance of the new estimates are pretty similar to the ones obtained with finlit_3, though with some interesting differences (Table 19). Concerning PIPs, the marginal effect is identical in 2014 for the indicator for risk diversification and mortgage. As for the subset PIPCs, that increased in the reduced sample by six percentage points as a proportion of PIPs between 2012 and 2014 (Table A.3), the marginal effects in 2014 are however pretty similar for all indicators except two (one answer for interest rate \& inflation and at least two answers; for previous waves, different indicators have the same marginal effects of finlit_3. In the case of PIPNCs, instead, marginal effects are significant for the indicators that do not affect PIPCs, and are always positively signed. Finally, marginal effects for FPAs are never significant in 2014.

The finding that correct answers to the risk diversification and to the mortgage questions, alone or when entered in two-answers indicators have marginal effects for PIPCs in 2014 similar to finlit_3, fits the literature according to which, though risk diversification is the least understood concept in financial literacy (Klapper et al. 2016), it is the one that matters most in retirement planning and precautionary savings (Lusardi and Michell 2011b; on US data, Lusardi 2015). A correct answer on mortgage hints at the positive role of a direct or indirect familiarity with this banking product in helping potential investors to better assess advisory services also on other financial products.

The evidence we provide on the role of which financial literacy indicator matter in pension choices sets the Italian case in recent years on a par with other countries. Previous studies on the overall participation rate in the private pension system had found instead significant effects for different indicators of financial literacy. The correct answer on the effect of inflation on the purchasing power is significant at the $10 \%$ level in the 2008 SHIW (Cappelletti and Guazzarotti 2010, table 4); the correct answer on interest rate, that has also the lowest proportion of correct answers, is significant at the $1 \%$ level in the 2006 SHIW (Fornero and Monticone 2011).

The debate on financial literacy and financial advice is mostly concerned with the issue on whether they are substitute or complement, considering the investment choices from the demand side perspective (Calcagno and Monticone 2015). The somehow sobering result of this paper on the limited role of financial literacy echoes a similar outcome in the investigation of the role of financial literacy in standard financial choices with a well defined dominated choice

\footnotetext{
${ }^{17}$ We report LPM estimates (bold italics) for non interacted financial indicators whenever the probit routine does not converge.
} 
(timing in trading, investment in own banks' bonds, CAPM suggested portfolio allocation) using data from a survey conducted by an Italian bank on a sample of clients with at least 10,000 euros in financial wealth (Guiso and Viviano 2015).

We surmise that the main contribution of this paper is to show how potential market structure features, though crudely proxied with the indicators of four city size classes, according to where HHs reside, help to better reframe the debate on dominated choices in the Italian experience with regards to the role of demand side explanatory variables (income, housing wealth and financial strength) as well as of financial literacy. Indeed, we detect a robust sales force effect (Hastings et al. 2017) across all SHIW waves and find that financial literacy shields to some extent investors from sellers' push factors, at least for some personal pension plans. In addition, these effect are detected especially after HHs have had time to assess the implications of an important pension system reform.

\section{TABLES 18-19 APPROXIMATELY HERE}

iii. From a methodological standpoint, it is in the end an impossible mission to disentangle the direct and reverse mutual causality feedbacks in a set of variables comprising financial education as well as personal experience in financial decisions that contribute to the acquisition of financial literacy (however measured), and the further layers of mutual links with saving, investment choices, level and composition of wealth.

One often proposed solution, namely searching for an exogenous variation in properly measured financial literacy, is hard to implement owing to data availability in surveys such as the SHIW. Within the literature of microeconometric methods applied to surveys or large administrative data set, the ingenuity in picking variables from a wide range of possible choices to instrument financial literacy indicators rarely provides unquestionably convincing evidence on causality. When attempted, a common result is that instrumental variables (IV) estimates of the effects of financial literacy are larger than the OLS estimates (Lusardi and Mitchell 2014). However, these results are to be assessed against the backdrop of well known sources of contrasting biases in the estimates of the expected positive correlation between financial literacy and financial outcomes, such as subscription rates in pension plans: upwards, owing to reverse causality (e.g. endogeneity by learning-by-doing effects on financial literacy of experience of saving or ownership of risky assets or bank relations) and unobserved heterogeneity (e.g. patience or forward-looking behaviour, personality, family background); downwards, because of measurement errors in computing indicators of financial literacy. 
Also the evidence on whether financial education causally improves financial outcomes, provided by studies relying on small-scale field experiments or large-scale natural experiments, is at best inconclusive (Hastings et al., 2012).

All in all, though in principle affected by upward and downward biases, the LPM results we commented upon provide therefore a lower bound for the financial literacy effects for an outcome such as personal pension choices (Lusardi and Mitchell 2014; Guiso and Viviano 2015). We surmise that the baseline specifications, with controls for a set of financial variables with positive bivariate correlations with financial literacy indicators - saving, risky instruments ownership, mortgagee status - should on the one hand reduce the upward bias. The use of different indicators of financial literacy should on the other hand deflate to some extent the downward bias due to measurement errors. The overall findings should therefore provide sufficiently convincing evidence on the positive, as expected, small but statistically significant, role of financial literacy in furthering subscription rates, at least in some personal pension plans.

\section{Conclusions and policy implications}

This paper investigates the puzzle of choices of dominated personal pension instruments in Italy (insurers' PIPs, instead of shares of insurers and banks' open funds FPAs) by household heads whose awareness on returns in private pension plans should have been raised by the higher retirement age and seniority requirements of the Fornero pension system reform legislated in December 2011. The empirical investigation exploited the availability of three waves of the biennial Bank of Italy's survey on households' income and wealth (SHIW) between 2010 and 2014.

Regarding the first research question on the possible role of sales force effects countervailing demand side determinants, we provide evidence of heterogeneity of demand side explanatory variables across SHIW waves, lending support to the hypothesis that the pension reform has affected households' choices for personal pensions. The financial strength indicators are indeed more statistically significant and economically relevant in the 2014 wave compared to the previous ones. Furthermore, subscription rates to PIPs are negatively and

significantly correlated with the size of the cities where employed HHs live. Our tentative interpretation is that this finding supports the hypothesis of a market structure effect on the supply side, because of a reduced local availability of bank branches, that can sell both FPAs 
and PIPs, compared with the countrywide network of post offices (owing to the universal postal service mandate of the state controlled Poste Italiane) and independent financial advisers associated with insurance companies - among which the one controlled by Poste Italiane. We are unable to proxy, owing to the data availability in SHIW, the further supply side effect associated to the reward incentives for financial advisers, included bank employees, tilted toward subscriptions in PIPs rather than in FPAs.

Regarding the second research question on whether financial literacy helps to shield investors from the persuasion effects of sales force and marketing investment, we provide evidence of a statistically significant dampening effect on the supply push toward PIPs, but only in the 2014 wave, the one fully affected by the implementation of the pension reform legislated at the end of 2011. This effect is even stronger for the subset of PIPs with voluntary matching employers' contributions (PIPCs). These findings, obtained when using the indicator of top financial literacy (correct answers to all three questions in the 2010 SHIW wave module), are however similar to the ones obtained with other indicators with one or two correct answers.

The policy implications we draw from our investigation are three.

First, financial literacy is the result of financial education as well as of personal experience in financial matters. The event of a pension system reform, widely believed to have been the main lever for shifting the Italian public debt sustainability markets' expectations from a bad to a good equilibrium, should have acted as a catalyst for employed household heads to reassess their private pension choices. The results provide indeed evidence for such a change between 2012 and 2014, namely the expected higher attractiveness for personal pension plan subscriptions, though with a market structure pushing towards dominated choices.

Second, public policies aimed at improving consumer financial outcomes, whatever the level of financial literacy, have to encompass a wide variety of regulatory approaches, to avoid excessive pressure by suppliers in concentrated local markets. Structural regulation is called for, in order to let workers to have a wide enough choice of local different financial outlets. Independent Fintech advisers and providers could play a role with online outlets supplementing the physical ones in local markets. In addition, besides designing more effective guidelines and supervision on how consultants inform and advise workers in their pension choices, it is crucial to restrain incentives and conflicts of interest that bias towards home-made products, following the best practices of the bans on inducement towards in-house products in the Netherlands and the UK (European Commission 2018).

Third, the finding that a higher financial literacy is not an unquestionable plus raises some doubts on the efficacy of investing resources in order to raise the level of general 
knowledge on basic tenets of financial literacy from only a demand side perspective. Better policies should aim at designing more focused packages that, besides concepts more related to specific financial products, include also notions on how market structure features can narrow down investors' available choices in the place they live in and how to manage this risk.

The SHIW data limitations with reference to the pension choices investigated in the Italian case, though the survey provides the best available dataset, suggest caution in drawing strong policy implications. We view as a key shortcoming that warrants future research, possibly supported by special questionnaires in SHIW, the lack of microdata on self-reported subscription rate associated with no contributions, in the year of reference or at all. Missing contributions by one fifth of enrollees in the private pensions system, a share that raises on COVIP data to one fourth for subscribers to personal pension plans and to almost one third for self-employed subscribers raise intriguing research questions on the roles of financial literacy and of adequate saving of workers who have to rely increasingly on their own investment to aim at an adequate pension income. 


\section{References}

Baffigi, A., L. Cannari, and G. D’Alessio (2016), Cinquant'anni di indagini sui bilanci delle famiglie italiane: storia, metodi, prospettive, Banca d'Italia, Questioni di Economia e Finanza no 368.

Banca d'Italia (2012), I bilanci delle famiglie italiane nell'anno 2010, Supplementi al Bollettino Statistico, Nuova Serie, XXII (6).

Banca d'Italia (2014), I bilanci delle famiglie italiane nell'anno 2012, Supplementi al Bollettino Statistico, Nuova Serie, XXIV (5).

Banca d'Italia (2015), I bilanci delle famiglie italiane nell'anno 2014, Supplementi al Bollettino Statistico, Nuova Serie, XXV (64).

Calcagno, R. and C. Monticone (2015), Financial literacy and the demand for financial advice, Journal of Banking and Finance, 50, 363-380.

Campbell, J.Y. (2006), Household Finance, Journal of Finance, 61(4), 1553-1604.

Cappelletti, G. and G. Guazzarotti (2010), Le scelte previdenziali nell'indagine sui bilanci delle famiglie della Banca d'Italia, Banca d'Italia, Questioni di Economia e Finanza no 77.

COVIP (various years), Relazione Annuale.

European Commission (2018), Distribution systems of retail investment products across the European Union. https://ec.europa.eu/info/sites/info/files/180425-retail-investment-products-distribution-systems_en.pdf.

Finseraas, H. and N. Jakobsson (2014), Does Information about the Pension System Affect Knowledge and Retirement Plans? Evidence from a Survey Experiment, Journal of Pension Economics and Finance, $13(3), 250-271$.

Fornero, E. and C. Monticone (2011), Financial literacy and pension plan participation in Italy, Journal of Pension Economics and Finance, 10 (4), 547-564.

Fornero, E., M.C. Rossi, and C. Urzí Brancati (2018), Information and Perceptions on Pensions. The Case of the 2011 Italian reform, Cerp Working Paper 176/18.

Guiso, L. and P. Sodini (2013), Household Finance: An Emerging Field, in G.M. Constantinides, M. Harris and R.M. Stulz (eds.) Handbook of the Economics of Finance, Elsevier, vol 2, Part B, 1397-1532.

Guiso, L. and E. Viviano (2015), How much can financial literacy help?, Review of Finance, 19, $1347-$ 1382.

Gurun, U.G., G. Matvos, and A. Seru (2016), Advertising Expensive Mortgages, Journal of Finance, LXXI (5), 2371-2416.

Gustman, A. L., T. S. Steinmeier, and N. Tabatabai (2008), Do workers know about their pension plan type? Comparing workers' and employers' pension information, in A. Lusardi (ed.), Overcoming the Saving Slump: How to Increase the Effectiveness of Financial Education and Savings Programs, Chicago, University of Chicago Press, 47-81.

Hastings, J.S., B.C. Madrian, and W.L. Skimmyhorn (2013), Financial Literacy, Financial Education, and Economic Outcomes, Annual Review of Economics, Annual Reviews, 5(1), 347-373.

Hastings, J.S., B.C. Madrian, and W.L. Skimmyhorn (2017), Sales Force and Competition in Financial Product Markets: The Case of Mexico’s Social Security Privatization, NBER Working Paper 18881. 
Hung, A.A., A.M. Parker, and J. Yoong (2009), Defining and Measuring Financial Literacy, Rand Corporation, WR-708.

Iscenko, Z, (2018), Choices of dominated mortgage products by UK consumers, Financial Conduct Authority Occasional Paper no 33.

Klapper, L., A. Lusardi, and P. van Oudheusden (2016), Financial Literacy Around the World: Insights from the Standard \& Poor's Ratings Services Global Financial Literacy Survey, http://gflec.org/wpcontent/uploads/2015/11/Finlit_paper_16_F2_singles.pdf.

Luciano, E., M.C. Rossi, and D. Sansone (2016), Financial Inclusion and Life Insurance Demand: Evidence from Italian Households, CERP Working Paper 156/16.

Lusardi, A. (2015), Risk literacy, Italian Economic Journal, 1, 5-23.

Lusardi, A. and O.S. Mitchell (2011a) Financial literacy and planning: implications for retirement wellbeing, in O.S. Mitchell and A. Lusardi (eds.) Financial literacy: implications for retirement security and the financial Marketplace, Oxford University Press, Oxford, 17-39.

Lusardi, A. and O.S. Mitchell (2011b) Financial literacy around the world: an overview, Journal of Pension Economics and Finance, 10(4), 497-508.

Lusardi, A. and O.S. Mitchell (2014), The economic importance of financial literacy: theory and evidence, Journal of Economic Literature, 52(1), 5-44.

OECD (2016), Pension Outlok 2016.

Poste Italiane (various years), Relazione finanziaria annuale, https://www.posteitaliane.it/it/bilanci-erelazioni.html\#/

SHIW (various years): see Banca d'Italia. 


\section{Appendix}

The wording of the financial literacy questionnaire in the 2010 SHIW.

1) Which type of mortgage allows you to determine the maximum amount and the number of instalments to pay in order to extinguish the debt? a. variable interest rate mortgage; b. fixed interest rate mortgage; c. variable interest rate and constant instalment mortgage; d. don't know; e. no answer.

2) You have a no-costs deposit of 1,000 euro offering a 1 per cent interest rate. Assume a 3 per cent inflation rate. Do you think that, when withdrawing your deposit one year later, you will be able to buy the same amount of goods that costs 1,000 euro today? a. yes; b. no, a minor amount; c. a greater amount; d. don't know; e. no answer.

3) Which investment strategy is riskier: a. invest in one company; b. invest in many companies; c. don't know; d. no answer. 


\section{Tables}

Table 1. Subscriptions ${ }^{1}$ and subscribers ${ }^{2}$ (in italics, years 2016 and 2017) to the Private Pension System (end-year data) ${ }^{3}$

\begin{tabular}{|c|c|c|c|c|c|c|c|}
\hline & 2007 & 2010 & 2015 & \multicolumn{2}{|c|}{2016} & \multicolumn{2}{|c|}{2017} \\
\hline Occupational Pension Funds (FPNs) & $1,988,639$ & $2,010,904$ & $2,419,103$ & $2,597,022$ & $2,560,686$ & $2,804,633$ & $2,761,623$ \\
\hline Open Pension Funds (FPAs) & 747,264 & 848,415 & $1,150,132$ & $1,258,979$ & $1,229,970$ & $1,374,205$ & $1,343,159$ \\
\hline "New" PIPs & 486,017 & $1,160,187$ & $2,600,790$ & $2,869,477$ & $2,759,135$ & $3,104,209$ & $2,969,187$ \\
\hline $\begin{array}{l}\text { "Pre-existing" Pension Funds } \\
\text { "Old" PIPs }\end{array}$ & $\begin{array}{l}680,673 \\
703,400\end{array}$ & $\begin{array}{l}667,930 \\
610,098\end{array}$ & $\begin{array}{l}645,612 \\
433,753\end{array}$ & $\begin{array}{l}653,971 \\
411,242\end{array}$ & $\begin{array}{l}619,851 \\
411,242\end{array}$ & $\begin{array}{l}643,341 \\
390,311\end{array}$ & $\begin{array}{l}610,490 \\
390,311\end{array}$ \\
\hline Grand Total $^{4}$ & $4,560,091$ & $5,271,884$ & $7,234,858$ & $\mathbf{7 , 7 8 7 , 4 8 8}$ & $7,146,968$ & $8,298,969$ & $7,585,969$ \\
\hline
\end{tabular}

Source: COVIP (2018). ${ }^{1}$ Data on subscriptions may include double counting referred to members enrolled in more than one pension fund. ${ }^{2}$ Data on subscribers enrolled in only one pension fund. ${ }^{3}$ Data including also subscriptions with no contributions in the reference year. ${ }^{4}$ FONDINPS is included. Excluded duplications for enrollees to old and new PIPs.

Table 2. Pension funds and sub-funds by investment - Compound net annual return rates (end-year percentages)

\begin{tabular}{|l|c|c|}
\hline & $\begin{array}{c}\mathbf{2 0 0 9 - 2 0 1 4} \\
\mathbf{5} \text { years }\end{array}$ & $\begin{array}{c}\mathbf{2 0 0 7 - 2 0 1 7} \\
\mathbf{1 0} \text { years }\end{array}$ \\
\hline Occupational Funds (FPNs) & $\mathbf{4 . 8}$ & $\mathbf{3 . 3}$ \\
\hline Guaranteed & 3.0 & 2.6 \\
\hline Bonds & 1.5 & 1.2 \\
\hline Mixed bonds & 5.1 & 3.8 \\
\hline Balanced & 5.4 & 3.6 \\
\hline All shares & 7.3 & 3.7 \\
\hline Open Funds (FPAs) & $\mathbf{5 . 2}$ & $\mathbf{3 . 0}$ \\
\hline Guaranteed & 2.7 & 2.2 \\
\hline Bonds & 3.2 & 2.7 \\
\hline Mixed bonds & 4.5 & 3.0 \\
\hline Balanced & 5.8 & 3.5 \\
\hline All shares & 7.2 & 3.4 \\
\hline "New" PIPs & & \\
Traditional Life Policies (Ramo I) & $\mathbf{3 . 2}$ & $\mathbf{2 . 8}$ \\
\hline Unit linked (Ramo III) & $\mathbf{4 . 9}$ & $\mathbf{2 . 2}$ \\
\hline Bonds & 1.9 & 1.6 \\
\hline Balanced & 3.7 & 2.4 \\
\hline All shares & 6.2 & 2.3 \\
\hline Memorandum items: & $\mathbf{2 . 4}$ & $\mathbf{2 . 1}$ \\
\hline TFR revaluation rate & & \\
\hline
\end{tabular}

Source: COVIP $(2015,2018)$. Return rates are net of management fees and of the substitute tax. 
Table. 3 Pension Funds. Synthetic Cost Indicator (SCI) by investment sub-funds (end-2017 data, per cent).

\begin{tabular}{|c|c|c|c|c|c|}
\hline \multicolumn{2}{|c|}{ Investment sub-funds } & \multicolumn{4}{|c|}{ SCI } \\
\hline & & 2 years & 5 years & 10 years & 35 years \\
\hline \multirow{3}{*}{ Guaranteed } & FPNs & 1.1 & 0.6 & 0.5 & 0.3 \\
\hline & FPAs & 2.3 & 1.4 & 1.2 & 1.1 \\
\hline & PIPs & 3.7 & 2.4 & 1.9 & 1.4 \\
\hline \multirow{3}{*}{ Bonds } & FPNs & 1.1 & 0.6 & 0.4 & 0.2 \\
\hline & FPAs & 1.9 & 1.3 & 1.1 & 0.9 \\
\hline & PIPs & 3.5 & 2.4 & 1.9 & 1.6 \\
\hline \multirow{3}{*}{ Balanced } & FPNs & 1.0 & 0.5 & 0.4 & 0.2 \\
\hline & FPAs & 2.4 & 1.6 & 1.4 & 1.3 \\
\hline & PIPs & 3.6 & 2.6 & 2.2 & 1.9 \\
\hline \multirow{3}{*}{ All shares } & FPNs & 1.2 & 0.6 & 0.4 & 0.2 \\
\hline & FPAs & 2.8 & 1.9 & 1.7 & 1.6 \\
\hline & PIPs & 4.5 & 3.2 & 2.7 & 2.3 \\
\hline \multicolumn{2}{|l|}{ FPNs } & 1,0 & 0.6 & 0.4 & 0.3 \\
\hline \multicolumn{2}{|l|}{$\min$} & 0.5 & 0.3 & 0.2 & 0.1 \\
\hline \multicolumn{2}{|l|}{$\max$} & 3.0 & 1.4 & 0.9 & 0.6 \\
\hline \multicolumn{2}{|l|}{ FPAs } & 2,3 & 1.6 & 1.3 & 1.2 \\
\hline \multicolumn{2}{|l|}{$\min$} & 0.5 & 0.5 & 0.5 & 0.1 \\
\hline \multicolumn{2}{|l|}{$\max$} & 5.1 & 3.4 & 2.8 & 2.4 \\
\hline \multicolumn{2}{|l|}{ PIPs } & 3,9 & 2.7 & 2.2 & 1.8 \\
\hline \multicolumn{2}{|l|}{ min } & 1.0 & 0.9 & 0.6 & 0.4 \\
\hline \multicolumn{2}{|l|}{$\max$} & 6.5 & 4.9 & 4.1 & 3.5 \\
\hline
\end{tabular}

Source: COVIP (2018). SCIs computed as simple averages for each sub-fund.

Table 4. Private pension plans ${ }^{1}$ subscription rate in balanced (BP) and unbalanced (UP) panels (\%)

\begin{tabular}{|c|c|c|c|}
\hline & 2010 & 2012 & 2014 \\
\hline & $\mathbf{B P}$ & $\mathbf{B P}$ & $\mathbf{B P}$ \\
\hline Any private pension plans & 23.7 & 23.2 & 23.7 \\
\hline FPNs & 3.0 & 3.6 & 2.3 \\
\hline Matching compulsory and voluntary employers' contribution (all plans) & 9.8 & 8.8 & 9.7 \\
\hline FPAs & 2.2 & 3.0 & 2.9 \\
\hline PIPs & 12.8 & 11.8 & 11.0 \\
\hline
\end{tabular}

Source: own computation from SHIW (various years). SHIW statistics adjusted for sample weights. ${ }^{1}$ SHIW data do not allow to distinguish between "old" and "new" PIPs.

Table 5. Correct answers on financial literacy: full sample and HHs in the BP 2010 wave subscribers to private pension plans (\%)

\begin{tabular}{|c|c|c|c|c|c|c|}
\hline & \multirow[b]{2}{*}{$\begin{array}{l}\text { Full } \\
\text { sample }\end{array}$} & \multicolumn{5}{|c|}{ Subscribers to } \\
\hline & & $\begin{array}{l}\text { Any private } \\
\text { pension plans }\end{array}$ & PIPs & PIPNCs $^{\mathrm{a}}$ & PIPCs $^{1}$ & FPAs \\
\hline None & 10.1 & 7.7 & 4.2 & 1.0 & 3.2 & 0.05 \\
\hline One & 17.7 & 14.1 & 6.5 & 3.2 & 3.3 & 1.3 \\
\hline Mortgage & 64.6 & 15.6 & 8.1 & 4.6 & 3.5 & 1.8 \\
\hline Interest rate and inflation & 75.6 & 17.5 & 8.7 & 4.7 & 4.0 & 2.0 \\
\hline Risk diversification & 58.9 & 18.7 & 9.6 & 5.5 & 4.1 & 2.2 \\
\hline Two & 35.2 & 15.8 & 7.5 & 4.3 & 3.2 & 1.8 \\
\hline Mortgage and interest rate & 53.6 & 16.6 & 8.5 & 4.7 & 3.8 & 2.0 \\
\hline Mortgage and risk diversification & 41.6 & 18.0 & 9.7 & 5.5 & 4.2 & 2.0 \\
\hline Risk diversification and interest rate & 51.0 & 19.3 & 10.0 & 5.5 & 4.5 & 2.3 \\
\hline At least two & 68.9 & 17.6 & 8.8 & 4.9 & 3.9 & 2.1 \\
\hline Three & 37.0 & 18.6 & 10.0 & 5.5 & 4.5 & 2.2 \\
\hline
\end{tabular}

Source: own computation from 2010 SHIW. ${ }^{1}$ PIPNCs and PIPCs stay for PIPs without and with matching voluntary employer's contributions. 
Table 6. Risky assets owners' by a) financial literacy levels and b) private pension plans subscribed (\%)

\begin{tabular}{|l|c|}
\hline \multicolumn{2}{|c|}{ Correct financial literacy answers } \\
\hline None & 0 \\
\hline One: Risk diversification & 15.5 \\
\hline Two: Risk diversification \& interest rate and inflation & 17.1 \\
\hline At least two & 14.0 \\
\hline Three & 16.7 \\
\hline \multicolumn{2}{|c|}{ Subscription rates to: } \\
\hline Any private pension plans ${ }^{1}$ & 28.4 \\
\hline - PIPs & 13.0 \\
\hline$P I P N C s$ & 8.2 \\
\hline$P I P C s$ & 4.8 \\
\hline - FPAs & 5.7 \\
\hline
\end{tabular}

Source: see Table 5. ${ }^{1}$ The grand total differs from the sum of sub-items.

Table 7. Positive savings by financial literacy levels (\%)

\begin{tabular}{|l|c|c|}
\hline & Correct answers & Wrong answers \\
\hline One: Risk diversification & 41.5 & 27.4 \\
\hline Two: Risk diversification \& interest rate and inflation & 41.3 & 30.0 \\
\hline At least two & 38.5 & 29.6 \\
\hline Three & 40.3 & 33.0 \\
\hline
\end{tabular}

Source: see Table 5 .

Table 8. Subscription rates to private pension plans by savings $(\%)$

\begin{tabular}{|c|c|c|c|c|}
\hline & \multicolumn{2}{|c|}{ BP } & \multicolumn{2}{|c|}{ UP } \\
\hline & Savings & No savings & Savings & No savings \\
\hline Any private pension plans ${ }^{1}$ & 26.6 & 14.4 & 25.3 & 13.4 \\
\hline - PIPs & 15.4 & 6.5 & 14.0 & 6.0 \\
\hline PIPCs & 6.6 & 3.1 & 6.6 & 3.1 \\
\hline - FPAs & 3.6 & 1.5 & 3.5 & 1.3 \\
\hline
\end{tabular}

Source: own computation from SHIW (various years); averaged (across 2010-2012-2014 waves) sample weighted data. ${ }^{1}$ The grand total differs from the sum of sub-items. 
Table 9. Subscription rate to any private pension fund (PENS). Cross section LPM estimates (full samples) ${ }^{1}$

\begin{tabular}{|c|c|c|c|}
\hline & 2010 & 2012 & 2014 \\
\hline equivalent income deciles & & & \\
\hline 2nd & $\begin{array}{c}0.0187 \\
(0.78)\end{array}$ & $\begin{array}{c}-0.00684 \\
(-0.35)\end{array}$ & $\begin{array}{c}-0.0414+ \\
(-1.71)\end{array}$ \\
\hline $3 r d$ & $\begin{array}{l}0.0285 \\
(1.17)\end{array}$ & $\begin{array}{l}0.0102 \\
(0.49)\end{array}$ & $\begin{array}{c}0.00578 \\
(0.22)\end{array}$ \\
\hline 4th & $\begin{array}{c}-0.00720 \\
(-0.32)\end{array}$ & $\begin{array}{l}0.0278 \\
(1.29)\end{array}$ & $\begin{array}{l}0.0218 \\
(0.83)\end{array}$ \\
\hline 5th & $\begin{array}{l}0.0813^{* *} \\
(3.24)\end{array}$ & $\begin{array}{c}0.0764^{* *} \\
(3.23)\end{array}$ & $\begin{array}{l}0.0119 \\
(0.47)\end{array}$ \\
\hline 6th & $\begin{array}{l}0.0703^{* *} \\
(2.87)\end{array}$ & $\begin{array}{l}0.0840 * * * \\
(3.51)\end{array}$ & $\begin{array}{l}0.0190 \\
(0.72)\end{array}$ \\
\hline 7th & $\begin{array}{l}0.0953^{* * *} \\
(3.70)\end{array}$ & $\begin{array}{l}0.130 * * * \\
(5.12)\end{array}$ & $\begin{array}{l}0.0689^{*} \\
(2.47)\end{array}$ \\
\hline 8th & $\begin{array}{l}0.125 * * * \\
(4.79)\end{array}$ & $\begin{array}{l}0.136^{* * *} \\
(5.26)\end{array}$ & $\begin{array}{l}0.0519+ \\
(1.86)\end{array}$ \\
\hline 9th & $\begin{array}{l}0.114 * * * \\
(4.20)\end{array}$ & $\begin{array}{l}0.156^{* * *} \\
(5.70)\end{array}$ & $\begin{array}{l}0.0789^{* *} \\
(2.78)\end{array}$ \\
\hline 10th & $\begin{array}{c}0.149 * * * \\
(5.21)\end{array}$ & $\begin{array}{l}0.180^{* * *} \\
(6.12)\end{array}$ & $\begin{array}{c}0.0883^{* *} \\
(2.94)\end{array}$ \\
\hline $\begin{array}{l}\text { demographic characteristics } \\
\text { age }\end{array}$ & $\begin{array}{c}0.0324 * * * \\
(6.33)\end{array}$ & $\begin{array}{c}0.0316 * * * \\
(6.57)\end{array}$ & $\begin{array}{c}0.0367 * * * \\
(7.33)\end{array}$ \\
\hline age squared & $\begin{array}{c}-0.000363^{* * *} \\
(-6.57)\end{array}$ & $\begin{array}{c}-0.000351^{* * *} \\
(-6.80)\end{array}$ & $\begin{array}{c}-0.000386 * * * \\
(-7.29)\end{array}$ \\
\hline female & $\begin{array}{c}-0.0541^{* * *} \\
(-4.86)\end{array}$ & $\begin{array}{c}-0.0485 * * * \\
(-4.36)\end{array}$ & $\begin{array}{c}-0.0572^{* * *} \\
(-4.99)\end{array}$ \\
\hline upper secondary & $\begin{array}{l}0.0400^{* *} \\
(3.26)\end{array}$ & $\begin{array}{l}0.0351^{* *} \\
(2.88)\end{array}$ & $\begin{array}{l}0.0244+ \\
(1.90)\end{array}$ \\
\hline university degree & $\begin{array}{l}0.0570^{* *} \\
(3.20)\end{array}$ & $\begin{array}{l}0.0615^{* * *} \\
(3.41)\end{array}$ & $\begin{array}{c}0.0457^{* *} \\
(2.60)\end{array}$ \\
\hline single & $\begin{array}{l}0.0535^{* *} \\
(2.90)\end{array}$ & $\begin{array}{c}0.00764 \\
(0.44)\end{array}$ & $\begin{array}{c}0.00693 \\
(0.42)\end{array}$ \\
\hline widow(er) & $\begin{array}{c}0.0440^{*} \\
(2.27)\end{array}$ & $\begin{array}{c}0.0442^{*} \\
(2.32)\end{array}$ & $\begin{array}{c}-0.00501 \\
(-0.30)\end{array}$ \\
\hline private employee & $\begin{array}{l}0.0394^{*} \\
(2.20)\end{array}$ & $\begin{array}{l}0.0528^{* *} \\
(3.09)\end{array}$ & $\begin{array}{l}0.0449^{*} \\
(2.57)\end{array}$ \\
\hline public employee & $\begin{array}{c}0.0117 \\
(0.78)\end{array}$ & $\begin{array}{l}0.0148 \\
(0.97)\end{array}$ & $\begin{array}{l}-0.00447 \\
(-0.27)\end{array}$ \\
\hline small firm (5- 49 workers) & $\begin{array}{c}0.0619 * * * \\
(3.56)\end{array}$ & $\begin{array}{l}0.0220 \\
(1.37)\end{array}$ & $\begin{array}{l}0.0378^{*} \\
(2.32)\end{array}$ \\
\hline medium firm (50-99 workers) & $\begin{array}{l}0.124^{* * *} \\
(3.95)\end{array}$ & $\begin{array}{l}0.126^{* * *} \\
(3.76)\end{array}$ & $\begin{array}{c}0.121^{* * *} \\
(4.12)\end{array}$ \\
\hline big firm (100+ workers) & $\begin{array}{c}0.225^{* * *} \\
(10.08)\end{array}$ & $\begin{array}{l}0.208^{* * *} \\
(9.40)\end{array}$ & $\begin{array}{l}0.188^{* * *} \\
(8.81)\end{array}$ \\
\hline resident in the North & $\begin{array}{l}0.0344^{* *} \\
(2.60)\end{array}$ & $\begin{array}{l}0.0136 \\
(1.04)\end{array}$ & $\begin{array}{l}0.00295 \\
(0.22)\end{array}$ \\
\hline resident in the Centre & $\begin{array}{c}0.00269 \\
(0.18)\end{array}$ & $\begin{array}{c}-0.00249 \\
(-0.17)\end{array}$ & $\begin{array}{l}-0.00843 \\
(-0.55)\end{array}$ \\
\hline $\begin{array}{l}\text { housing wealth } \\
\text { home owner }\end{array}$ & $\begin{array}{l}0.0105 \\
(0.78)\end{array}$ & $\begin{array}{c}0.00552 \\
(0.41)\end{array}$ & $\begin{array}{c}0.0240+ \\
(1.71)\end{array}$ \\
\hline mortgagee & $\begin{array}{l}0.0234 \\
(1.48)\end{array}$ & $\begin{array}{c}0.00949 \\
(0.60)\end{array}$ & $\begin{array}{l}0.00942 \\
(0.59)\end{array}$ \\
\hline $\begin{array}{l}\text { financial strength } \\
\text { positive saving }\end{array}$ & $\begin{array}{c}0.0226+ \\
(1.89)\end{array}$ & $\begin{array}{c}0.00464 \\
(0.34)\end{array}$ & $\begin{array}{l}0.0303^{*} \\
(2.23)\end{array}$ \\
\hline $\begin{array}{l}\text { risky asset owner } \\
\text { sellers' local availability }\end{array}$ & $\begin{array}{c}0.0781^{* * *} \\
(4.29)\end{array}$ & $\begin{array}{l}0.0804^{* * *} \\
(3.77)\end{array}$ & $\begin{array}{l}0.0695^{* * *} \\
(3.49)\end{array}$ \\
\hline $\begin{array}{l}\text { medium city } \\
\text { ( } 20,000 \text { to } 40,000 \text { inhabitants) }\end{array}$ & $\begin{array}{c}-0.0534^{* * *} \\
(-3.30)\end{array}$ & $\begin{array}{c}-0.0354^{*} \\
(-2.23)\end{array}$ & $\begin{array}{c}-0.0232 \\
(-1.38)\end{array}$ \\
\hline $\begin{array}{l}\text { large city } \\
(40,000 \text { to } 500,000 \text { inhabitants })\end{array}$ & $\begin{array}{c}-0.0247+ \\
(-1.85)\end{array}$ & $\begin{array}{c}-0.00464 \\
(-0.35)\end{array}$ & $\begin{array}{c}-0.0511^{* * *} \\
(-3.67)\end{array}$ \\
\hline $\begin{array}{l}\text { big city }(500,000+) \\
(500,000+\text { inhabitants })\end{array}$ & $\begin{array}{c}-0.0606 * * \\
(-3.05)\end{array}$ & $\begin{array}{c}-0.0261 \\
(-1.27)\end{array}$ & $\begin{array}{c}-0.0838^{* * *} \\
(-4.05)\end{array}$ \\
\hline constant & $\begin{array}{c}-0.687 * * * \\
(-5.87)\end{array}$ & $\begin{array}{c}-0.679 * * * \\
(-6.07)\end{array}$ & $\begin{array}{c}-0.767 * * * \\
(-6.51)\end{array}$ \\
\hline $\begin{array}{l}\text { Number of obs } \\
\text { R-squared }\end{array}$ & $\begin{array}{c}5,347 \\
0.1098 \\
F(30,5316)=20.26^{* * *}\end{array}$ & $\begin{array}{c}5,158 \\
0.1139 \\
F(30,5127)=20.25^{* * *}\end{array}$ & $\begin{array}{c}4,810 \\
0.0999 \\
F(30,4779)=15.75^{* * *}\end{array}$ \\
\hline $\begin{array}{l}\text { Exclusion restrictions tests: } \\
\text { T1: saving=risky assets }=0 \\
\text { T2: } \text { medium=large }=\text { big city }=0 \\
\text { T3: } \mathrm{T} 1 \& \mathrm{~T} 2\end{array}$ & $\begin{array}{l}F(2,5316)=11.86^{* * *} \\
F(3,5316)=5.05^{* *} \\
F(5,5316)=7.81^{* * *}\end{array}$ & $\begin{array}{l}F(2,5127)=7.41^{* * *} \\
F(3,5127)=2.27+ \\
F(5,5127)=4.35^{* *}\end{array}$ & $\begin{array}{l}\mathrm{F}(2,4779)=9.44^{* * *} \\
\mathrm{~F}(3,4779)=7.29^{* * *} \\
\mathrm{~F}(5,4779)=8.74^{* * *}\end{array}$ \\
\hline
\end{tabular}

Source: own elaboration from SHIW $(2010,2012,2014)$. t-statistics out of robust SEs within brackets; ${ }^{+} \mathrm{p}<0.10,{ }^{*} \mathrm{p}<0.05, * * \mathrm{p}<0.01, * * *$ $\mathrm{p}<0.001$. $^{1} 25$ to 65 years old employed household heads. Reference categories: first decile of equivalent per household income, male, up to lower secondary degree, married, self-employed, micro firm (1-4 workers), residence in a small city (up to 20,000 inhabitants) and in the South and Inlands, no home ownership, no mortgage, no saving, no risky assets ownership. 
Table 10. Subscription rate to PIPs. Cross section LPM estimates (full samples) ${ }^{1}$

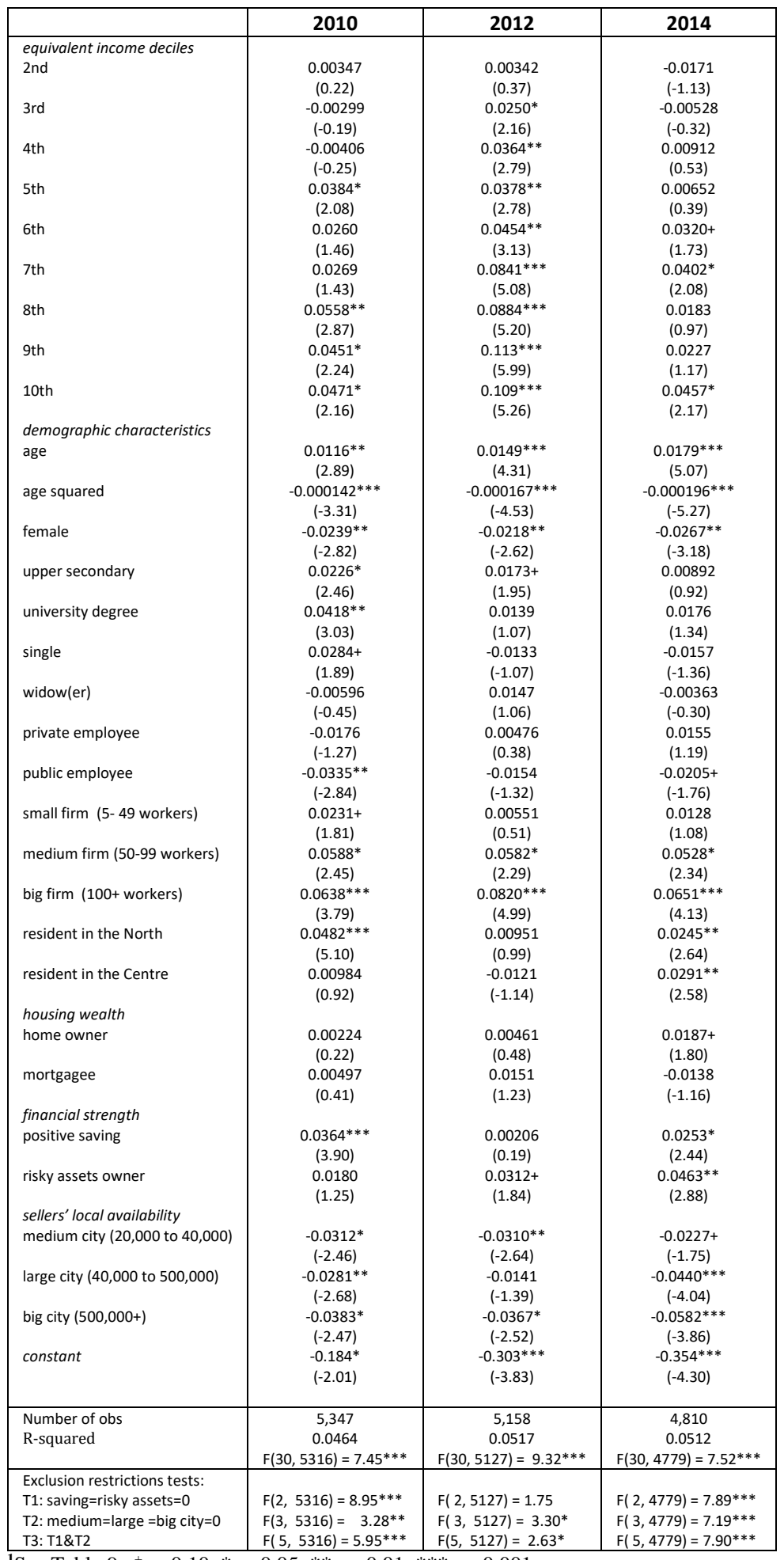

${ }^{1}$ See Table 9. ${ }^{+} \mathrm{p}<0.10,{ }^{*} \mathrm{p}<0.05, * * \mathrm{p}<0.01, * * * \mathrm{p}<0.001$. 


\begin{tabular}{|c|c|c|c|c|c|c|}
\hline & \multicolumn{2}{|c|}{2010} & \multicolumn{2}{|c|}{2012} & \multicolumn{2}{|c|}{2014} \\
\hline & PIPCs & PIPNCs & PIPCs & PIPNCs & PIPCs & PIPNCs \\
\hline eqv. income deciles & & & & & & \\
\hline 2nd & $\begin{array}{c}-0.0053 \\
(-0.48)\end{array}$ & $\begin{array}{c}0.00877 \\
(0.75)\end{array}$ & $\begin{array}{c}-0.00896+ \\
(-1.67)\end{array}$ & $\begin{array}{l}0.0124 \\
(1.64)\end{array}$ & $\begin{array}{l}-0.00196 \\
(-0.21)\end{array}$ & $\begin{array}{c}-0.0151 \\
(-1.24)\end{array}$ \\
\hline $3 r d$ & $\begin{array}{c}-0.000206 \\
(-0.02)\end{array}$ & $\begin{array}{c}-0.00278 \\
(-0.27)\end{array}$ & $\begin{array}{c}0.0000499 \\
(0.01)\end{array}$ & $\begin{array}{c}0.0250^{* *} \\
(2.88)\end{array}$ & $\begin{array}{c}0.00933 \\
(0.85)\end{array}$ & $\begin{array}{c}-0.0146 \\
(-1.17)\end{array}$ \\
\hline 4th & $\begin{array}{c}-0.00336 \\
(-0.30)\end{array}$ & $\begin{array}{c}-0.000703 \\
(-0.06)\end{array}$ & $\begin{array}{l}0.0062 \\
(0.71)\end{array}$ & $\begin{array}{c}0.0302 * * \\
(3.05)\end{array}$ & $\begin{array}{l}0.0177 \\
(1.52)\end{array}$ & $\begin{array}{c}-0.00853 \\
(-0.66)\end{array}$ \\
\hline 5th & $\begin{array}{l}0.0113 \\
(0.87)\end{array}$ & $\begin{array}{c}0.0272^{*} \\
(1.98)\end{array}$ & $\begin{array}{c}0.0184+ \\
(1.74)\end{array}$ & $\begin{array}{l}0.0193^{*} \\
(2.20)\end{array}$ & $\begin{array}{c}0.00668 \\
(0.65)\end{array}$ & $\begin{array}{c}-0.000154 \\
(-0.01)\end{array}$ \\
\hline 6th & $\begin{array}{c}-0.00898 \\
(-0.79)\end{array}$ & $\begin{array}{c}0.0349 * \\
(2.48)\end{array}$ & $\begin{array}{c}0.0234^{*} \\
(2.11)\end{array}$ & $\begin{array}{l}0.0221^{*} \\
(2.28)\end{array}$ & $\begin{array}{c}0.0223+ \\
(1.83)\end{array}$ & $\begin{array}{c}0.00968 \\
(0.67)\end{array}$ \\
\hline 7th & $\begin{array}{c}0.00749 \\
(0.60)\end{array}$ & $\begin{array}{c}0.0194 \\
(1.33)\end{array}$ & $\begin{array}{c}0.0214^{*} \\
(2.00)\end{array}$ & $\begin{array}{c}0.0627^{* * *} \\
(4.82)\end{array}$ & $\begin{array}{c}0.0219+ \\
(1.76)\end{array}$ & $\begin{array}{l}0.0183 \\
(1.20)\end{array}$ \\
\hline 8th & $\begin{array}{c}0.0286^{*} \\
(2.10)\end{array}$ & $\begin{array}{c}0.0273+ \\
(1.89)\end{array}$ & $\begin{array}{c}0.0463^{* * *} \\
(3.63)\end{array}$ & $\begin{array}{c}0.0421^{* * *} \\
(3.60)\end{array}$ & $\begin{array}{c}0.00424 \\
(0.35)\end{array}$ & $\begin{array}{l}0.0141 \\
(0.95)\end{array}$ \\
\hline 9th & $\begin{array}{c}0.00438 \\
(0.34)\end{array}$ & $\begin{array}{c}0.0407^{*} \\
(2.56)\end{array}$ & $\begin{array}{c}0.0570^{* * *} \\
(4.22)\end{array}$ & $\begin{array}{c}0.0559 * * * \\
(4.05)\end{array}$ & $\begin{array}{l}0.0125 \\
(1.00)\end{array}$ & $\begin{array}{l}0.0102 \\
(0.66)\end{array}$ \\
\hline $\begin{array}{l}\text { 10th } \\
\text { demographic chars }\end{array}$ & $\begin{array}{c}0.00431 \\
(0.31)\end{array}$ & $\begin{array}{l}0.0428^{*} \\
(2.45)\end{array}$ & $\begin{array}{c}0.0482^{* * *} \\
(3.32)\end{array}$ & $\begin{array}{c}0.0607^{* * *} \\
(3.91)\end{array}$ & $\begin{array}{l}0.014 \\
(1.07)\end{array}$ & $\begin{array}{c}0.0317+ \\
(1.87)\end{array}$ \\
\hline age & $\begin{array}{c}0.00176 \\
(0.65)\end{array}$ & $\begin{array}{c}0.00983^{* *} \\
(3.14)\end{array}$ & $\begin{array}{c}0.00528^{*} \\
(2.22)\end{array}$ & $\begin{array}{c}0.00959 * * * \\
(3.66)\end{array}$ & $\begin{array}{c}0.00794^{* *} \\
(3.26)\end{array}$ & $\begin{array}{l}0.00995^{* * *} \\
\quad(3.75)\end{array}$ \\
\hline age squared & $\begin{array}{c}-0.0000262 \\
(-0.91)\end{array}$ & $\begin{array}{c}-0.000116^{* * *} \\
(-3.45)\end{array}$ & $\begin{array}{c}-0.0000621^{*} \\
(-2.47)\end{array}$ & $\begin{array}{c}-0.000105 * * * \\
(-3.72)\end{array}$ & $\begin{array}{c}-0.0000889 * * * \\
(-3.48)\end{array}$ & $\begin{array}{c}-0.000107^{* * *} \\
(-3.81)\end{array}$ \\
\hline female & $\begin{array}{c}-0.00822 \\
(-1.43)\end{array}$ & $\begin{array}{c}-0.0157^{*} \\
(-2.38)\end{array}$ & $\begin{array}{c}-0.0134^{*} \\
(-2.27)\end{array}$ & $\begin{array}{c}-0.00833 \\
(-1.35)\end{array}$ & $\begin{array}{c}-0.0261^{* * *} \\
(-4.21)\end{array}$ & $\begin{array}{c}-0.000583 \\
(-0.10)\end{array}$ \\
\hline upper secondary & $\begin{array}{c}0.00924 \\
(1.43)\end{array}$ & $\begin{array}{c}0.0134+ \\
(1.93)\end{array}$ & $\begin{array}{c}0.0104 \\
(1.55)\end{array}$ & $\begin{array}{c}0.00688 \\
(1.12)\end{array}$ & $\begin{array}{c}-0.00128 \\
(-0.17)\end{array}$ & $\begin{array}{l}0.0102 \\
(1.56)\end{array}$ \\
\hline university & $\begin{array}{c}-0.00525 \\
(-0.62)\end{array}$ & $\begin{array}{c}0.0470 * * * \\
(4.14)\end{array}$ & $\begin{array}{c}-0.0121 \\
(-1.39)\end{array}$ & $\begin{array}{c}0.0261^{* *} \\
(2.58)\end{array}$ & $\begin{array}{c}-0.00172 \\
(-0.18)\end{array}$ & $\begin{array}{c}0.0193^{*} \\
(1.99)\end{array}$ \\
\hline single & $\begin{array}{c}-0.00502 \\
(-0.56)\end{array}$ & $\begin{array}{c}0.0335^{* *} \\
(2.60)\end{array}$ & $\begin{array}{c}-0.0206^{* *} \\
(-2.59)\end{array}$ & $\begin{array}{c}0.00726 \\
(0.73)\end{array}$ & $\begin{array}{c}-0.0200^{* *} \\
(-2.60)\end{array}$ & $\begin{array}{l}0.0043 \\
(0.48)\end{array}$ \\
\hline widow(er) & $\begin{array}{c}-0.0161^{*} \\
(-2.09)\end{array}$ & $\begin{array}{c}0.0101 \\
(0.92)\end{array}$ & $\begin{array}{c}-0.0083 \\
(-0.95)\end{array}$ & $\begin{array}{c}0.0230^{*} \\
(2.06)\end{array}$ & $\begin{array}{c}-0.00115 \\
(-0.13)\end{array}$ & $\begin{array}{l}-0.00248 \\
(-0.29)\end{array}$ \\
\hline private employee & $\begin{array}{c}-0.00292 \\
(-0.41)\end{array}$ & $\begin{array}{l}-0.0147 \\
(-1.21)\end{array}$ & $\begin{array}{c}0.0242 * * * \\
(3.42)\end{array}$ & $\begin{array}{c}-0.0195+ \\
(-1.84)\end{array}$ & $\begin{array}{c}0.0315^{* * *} \\
(3.85)\end{array}$ & $\begin{array}{l}-0.016 \\
(-1.51)\end{array}$ \\
\hline public employee & $\begin{array}{c}0.00624 \\
(0.91)\end{array}$ & $\begin{array}{c}-0.0397^{* * *} \\
(-3.98)\end{array}$ & $\begin{array}{c}0.0167^{* *} \\
(2.83)\end{array}$ & $\begin{array}{c}-0.0321^{* *} \\
(-3.12)\end{array}$ & $\begin{array}{c}0.0172^{* *} \\
(2.65)\end{array}$ & $\begin{array}{c}-0.0377^{* * *} \\
(-3.83)\end{array}$ \\
\hline $\begin{array}{l}\text { small firm (5- } 49 \\
\text { workers) }\end{array}$ & $\begin{array}{c}0.0211^{* *} \\
(3.07)\end{array}$ & $\begin{array}{c}0.00198 \\
(0.18)\end{array}$ & $\begin{array}{l}0.0107 \\
(1.43)\end{array}$ & $\begin{array}{c}-0.00517 \\
(-0.63)\end{array}$ & $\begin{array}{c}0.00743 \\
(0.87)\end{array}$ & $\begin{array}{c}0.00538 \\
(0.62)\end{array}$ \\
\hline $\begin{array}{l}\text { medium firm (50-99 } \\
\text { workers) }\end{array}$ & $\begin{array}{c}0.0594^{* * *} \\
(3.38)\end{array}$ & $\begin{array}{c}-0.000529 \\
(-0.03)\end{array}$ & $\begin{array}{c}0.0433^{*} \\
(2.22)\end{array}$ & $\begin{array}{c}0.0149 \\
(0.84)\end{array}$ & $\begin{array}{c}0.0307+ \\
(1.82)\end{array}$ & $\begin{array}{l}0.0221 \\
(1.36)\end{array}$ \\
\hline big firm (100+ workers) & $\begin{array}{c}0.0873^{* * *} \\
(7.30)\end{array}$ & $\begin{array}{c}-0.0235+ \\
(-1.86)\end{array}$ & $\begin{array}{c}0.0976^{* * *} \\
(7.36)\end{array}$ & $\begin{array}{l}-0.0156 \\
(-1.47)\end{array}$ & $\begin{array}{c}0.0756^{* * *} \\
(5.82)\end{array}$ & $\begin{array}{l}-0.0105 \\
(-1.08)\end{array}$ \\
\hline resident in the North & $\begin{array}{c}0.0232^{* * *} \\
(3.74)\end{array}$ & $\begin{array}{c}0.0249 * * * \\
(3.39)\end{array}$ & $\begin{array}{c}0.0176^{* *} \\
(2.71)\end{array}$ & $\begin{array}{c}-0.00806 \\
(-1.09)\end{array}$ & $\begin{array}{c}0.0279 * * * \\
(4.15)\end{array}$ & $\begin{array}{c}-0.00337 \\
(-0.50)\end{array}$ \\
\hline $\begin{array}{l}\text { resident in the Centre } \\
\text { housing wealth }\end{array}$ & $\begin{array}{c}0.00452 \\
(0.64)\end{array}$ & $\begin{array}{c}0.00532 \\
(0.65)\end{array}$ & $\begin{array}{c}0.00234 \\
(0.33)\end{array}$ & $\begin{array}{c}-0.0144+ \\
(-1.77)\end{array}$ & $\begin{array}{l}0.0123 \\
(1.56)\end{array}$ & $\begin{array}{l}0.0168^{*} \\
(1.99)\end{array}$ \\
\hline home owner & $\begin{array}{c}0.00754 \\
(1.14)\end{array}$ & $\begin{array}{c}-0.00531 \\
(-0.63)\end{array}$ & $\begin{array}{c}0.0104 \\
(1.55)\end{array}$ & $\begin{array}{c}-0.00578 \\
(-0.79)\end{array}$ & $\begin{array}{c}0.0192^{*} \\
(2.51)\end{array}$ & $\begin{array}{c}-0.00049 \\
(-0.07)\end{array}$ \\
\hline mortgagee & $\begin{array}{c}0.00715 \\
(0.81)\end{array}$ & $\begin{array}{c}-0.00218 \\
(-0.24)\end{array}$ & $\begin{array}{c}0.00442 \\
(0.47)\end{array}$ & $\begin{array}{l}0.0106 \\
(1.26)\end{array}$ & $\begin{array}{c}-0.00522 \\
(-0.56)\end{array}$ & $\begin{array}{c}-0.00859 \\
(-1.08)\end{array}$ \\
\hline $\begin{array}{l}\text { financial strength } \\
\text { positive saving }\end{array}$ & $\begin{array}{c}0.00995 \\
(1.58)\end{array}$ & $\begin{array}{c}0.0264 * * * \\
(3.63)\end{array}$ & $\begin{array}{r}-0.0054 \\
(-0.74)\end{array}$ & $\begin{array}{c}0.00746 \\
(0.92)\end{array}$ & $\begin{array}{c}0.0200^{* *} \\
(2.64)\end{array}$ & $\begin{array}{c}0.00525 \\
(0.70)\end{array}$ \\
\hline $\begin{array}{l}\text { risky assets owner } \\
\text { sellers' local avail. }\end{array}$ & $\begin{array}{c}0.00169 \\
(0.19)\end{array}$ & $\begin{array}{l}0.0163 \\
(1.38)\end{array}$ & $\begin{array}{c}0.00621 \\
(0.51)\end{array}$ & $\begin{array}{c}0.0250^{*} \\
(1.99)\end{array}$ & $\begin{array}{l}0.0126 \\
(1.11)\end{array}$ & $\begin{array}{c}0.0337^{* *} \\
(2.76)\end{array}$ \\
\hline $\begin{array}{l}\text { medium city }(20,000 \text { to } \\
40,000)\end{array}$ & $\begin{array}{c}-0.0203^{*} \\
(-2.28)\end{array}$ & $\begin{array}{c}-0.0109 \\
(-1.13)\end{array}$ & $\begin{array}{c}-0.00251 \\
(-0.29)\end{array}$ & $\begin{array}{c}-0.0284^{* * *} \\
(-3.35)\end{array}$ & $\begin{array}{c}-0.0163+ \\
(-1.68)\end{array}$ & $\begin{array}{c}-0.00636 \\
(-0.70)\end{array}$ \\
\hline $\begin{array}{l}\text { large city }(40,000 \text { to } \\
500,000)\end{array}$ & $\begin{array}{l}-0.0198^{* *} \\
(-2.69)\end{array}$ & $\begin{array}{l}-0.00825 \\
(-1.03)\end{array}$ & $\begin{array}{c}0.00568 \\
(0.79)\end{array}$ & $\begin{array}{c}-0.0198^{* *} \\
(-2.62)\end{array}$ & $\begin{array}{c}-0.0232 * * \\
(-2.79)\end{array}$ & $\begin{array}{c}-0.0208 * * \\
(-2.76)\end{array}$ \\
\hline $\begin{array}{l}\text { big city }(500,000+) \\
\text { constant }\end{array}$ & $\begin{array}{c}-0.0203+ \\
(-1.95) \\
-0.012 \\
(-0.19) \\
\end{array}$ & $\begin{array}{c}-0.0179 \\
(-1.50) \\
-0.172^{*} \\
(-2.42) \\
\end{array}$ & $\begin{array}{c}-0.00416 \\
(-0.39) \\
-0.134^{*} \\
(-2.43) \\
\end{array}$ & $\begin{array}{c}-0.0325^{* *} \\
(-3.09) \\
-0.169^{* *} \\
(-2.86)\end{array}$ & $\begin{array}{c}-0.0378^{* * *} \\
(-3.44) \\
-0.179 * * \\
(-3.12) \\
\end{array}$ & $\begin{array}{c}-0.0204+ \\
(-1.87) \\
-0.176^{* *} \\
(-2.84)\end{array}$ \\
\hline $\begin{array}{l}\text { Number of obs } \\
\text { R-squared }\end{array}$ & $\begin{array}{r}5,347 \\
0.0392 \\
F(30,5316)=4 .\end{array}$ & $\begin{array}{r}5,347 \\
0.0338 \\
30,5316)=5\end{array}$ & $\begin{array}{r}5,158 \\
0.0608 \\
5127)=6\end{array}$ & $\begin{array}{c}5,158 \\
0.0262 \\
5127)=4.28 * * *\end{array}$ & $\begin{array}{r}4,810 \\
0.0530 \\
F(30,4779)=5 .\end{array}$ & $\begin{array}{c}4,810 \\
0.0244 \\
30,4779)=3.46 * * *\end{array}$ \\
\hline $\begin{array}{l}\text { Exclusion restrictions } \\
\text { tests: }\end{array}$ & $F(30,5316)=$ & $0,5316)=$ & $512 / 1=$ & $15121)=$ & $F(30,4 / / 9)=$ & $30,4 / / 9)=$ \\
\hline $\begin{array}{l}\text { T1: saving=risky } \\
\text { assets }=0\end{array}$ & $F(2,5316)=1.29$ & $F(2,5316)=8.37 * * *$ & $F(2,5127)=0.40$ & $F(2,5127)=2.63+$ & $F(2,4779)=4.21^{*}$ & $F(2,4779)=4.44^{*}$ \\
\hline $\begin{array}{l}\text { T2: } \text { medium=large =big } \\
\text { city }=0\end{array}$ & $F(3,5316)=2.74^{*}$ & $F(3,5316)=0.87$ & $F(3,5127)=0.59$ & $F(3,5127)=4.69^{*}$ & $F(3,4779)=4.37^{* * *}$ & $F(3,4779)=3.06^{*}$ \\
\hline T3: T1\&T2 & $F(5,5316)=2.17^{*}$ & $F(5,5316)=4.18^{* * *}$ & $F(5,5127)=0.46$ & $F(5,5127)=3.62^{*}$ & $F(5,4779)=4.38^{* * *}$ & $F(5,4779)=3.75^{* * *}$ \\
\hline
\end{tabular}

\begin{tabular}{|c|c|c|} 
T3: T1\&T2 & $F(5,5316)=2.17 *$ & $F(5,5316)=4.18^{* * *}$ \\
${ }^{1}$ See Table 9. ${ }^{+} \mathrm{p}<0.10,{ }^{*} \mathrm{p}<0.05,{ }^{*} * \mathrm{p}<0.01, * * * \mathrm{p}<0.001$.
\end{tabular} 
Table 12. Subscription rates to FPAs. Cross section LPM estimates (full samples) ${ }^{1}$

\begin{tabular}{|c|c|c|c|}
\hline & 2010 & 2012 & 2014 \\
\hline \multicolumn{4}{|l|}{ equivalent income deciles } \\
\hline 2nd & $\begin{array}{c}-0.00228 \\
(-0.33)\end{array}$ & $\begin{array}{c}-0.000367 \\
(-0.13)\end{array}$ & $\begin{array}{c}0.00131 \\
(0.29)\end{array}$ \\
\hline 3 rd & $\begin{array}{c}-0.00725 \\
(-1.13)\end{array}$ & $\begin{array}{c}-0.00201 \\
(-0.51)\end{array}$ & $\begin{array}{c}-0.00274 \\
(-0.65)\end{array}$ \\
\hline 4th & $\begin{array}{c}-0.00472 \\
(-0.69)\end{array}$ & $\begin{array}{c}0.00387 \\
(0.78)\end{array}$ & $\begin{array}{c}0.00239 \\
(0.41)\end{array}$ \\
\hline 5th & $\begin{array}{c}-0.00223 \\
(-0.31)\end{array}$ & $\begin{array}{c}0.0229 * * \\
(2.93)\end{array}$ & $\begin{array}{c}0.00718 \\
(1.13)\end{array}$ \\
\hline 6th & $\begin{array}{c}-0.000750 \\
(-0.10)\end{array}$ & $\begin{array}{c}0.000782 \\
(0.14)\end{array}$ & $\begin{array}{r}0.0107 \\
(1.45)\end{array}$ \\
\hline 7th & $\begin{array}{l}0.0117 \\
(1.30)\end{array}$ & $\begin{array}{l}0.0123 \\
(1.55)\end{array}$ & $\begin{array}{c}0.0148+ \\
(1.86)\end{array}$ \\
\hline 8th & $\begin{array}{c}-0.000564 \\
(-0.07)\end{array}$ & $\begin{array}{c}0.0151+ \\
(1.86)\end{array}$ & $\begin{array}{c}0.0106 \\
(1.28)\end{array}$ \\
\hline 9th & $\begin{array}{c}0.0219^{*} \\
(2.22)\end{array}$ & $\begin{array}{c}0.0212^{*} \\
(2.23)\end{array}$ & $\begin{array}{c}0.0101 \\
(1.19)\end{array}$ \\
\hline 10th & $\begin{array}{c}0.0324^{* *} \\
(2.87)\end{array}$ & $\begin{array}{c}0.0401^{* * *} \\
(3.87)\end{array}$ & $\begin{array}{c}0.0169 \\
(1.62)\end{array}$ \\
\hline \multicolumn{4}{|l|}{ demographic characteristics } \\
\hline age & $\begin{array}{c}0.00735^{* * *} \\
(4.23)\end{array}$ & $\begin{array}{c}0.00529^{* *} \\
(3.27)\end{array}$ & $\begin{array}{c}0.00384^{*} \\
(2.13)\end{array}$ \\
\hline age squared & $\begin{array}{c}-0.0000801^{* * *} \\
(-4.32)\end{array}$ & $\begin{array}{c}-0.0000576^{* * *} \\
(-3.33)\end{array}$ & $\begin{array}{c}-0.0000363+ \\
(-1.85)\end{array}$ \\
\hline female & $\begin{array}{c}-0.0114^{*} \\
(-2.56)\end{array}$ & $\begin{array}{c}-0.00741+ \\
(-1.76)\end{array}$ & $\begin{array}{c}-0.00970^{*} \\
(-2.05)\end{array}$ \\
\hline upper secondary & $\begin{array}{c}0.0113^{*} \\
(2.58)\end{array}$ & $\begin{array}{c}-0.00119 \\
(-0.26)\end{array}$ & $\begin{array}{c}0.00316 \\
(0.68)\end{array}$ \\
\hline university degree & $\begin{array}{c}0.00778 \\
(1.03)\end{array}$ & $\begin{array}{c}0.00669 \\
(0.91)\end{array}$ & $\begin{array}{c}0.00313 \\
(0.44)\end{array}$ \\
\hline single & $\begin{array}{c}0.00738 \\
(0.97)\end{array}$ & $\begin{array}{c}0.0111 \\
(1.46)\end{array}$ & $\begin{array}{c}0.00373 \\
(0.53)\end{array}$ \\
\hline widow(er) & $\begin{array}{l}0.0111 \\
(1.43)\end{array}$ & $\begin{array}{c}0.00397 \\
(0.60)\end{array}$ & $\begin{array}{c}-0.000831 \\
(-0.13)\end{array}$ \\
\hline private employee & $\begin{array}{c}0.0128^{*} \\
(2.40)\end{array}$ & $\begin{array}{c}0.000772 \\
(0.18)\end{array}$ & $\begin{array}{c}0.00189 \\
(0.28)\end{array}$ \\
\hline public employee & $\begin{array}{c}0.00424 \\
(0.88)\end{array}$ & $\begin{array}{c}0.00134 \\
(0.24)\end{array}$ & $\begin{array}{c}-0.00384 \\
(-0.56)\end{array}$ \\
\hline small firm (5- 49 workers) & $\begin{array}{l}0.0101 * \\
(2.01)\end{array}$ & $\begin{array}{c}0.0105^{* *} \\
(2.67)\end{array}$ & $\begin{array}{c}-0.00514 \\
(-0.97)\end{array}$ \\
\hline medium firm (50-99 workers) & $\begin{array}{c}0.00759 \\
(0.74)\end{array}$ & $\begin{array}{c}0.0249+ \\
(1.85)\end{array}$ & $\begin{array}{c}0.0111 \\
(0.99)\end{array}$ \\
\hline big firm (100+ workers) & $\begin{array}{c}0.0605^{* * * *} \\
(6.24)\end{array}$ & $\begin{array}{c}0.0414^{* * *} \\
(4.90)\end{array}$ & $\begin{array}{l}0.0303^{* * *} \\
(3.44)\end{array}$ \\
\hline resident in the North & $\begin{array}{c}0.00132 \\
(0.27)\end{array}$ & $\begin{array}{c}-0.00616 \\
(-1.16)\end{array}$ & $\begin{array}{c}0.00327 \\
(0.59)\end{array}$ \\
\hline resident in the Centre & $\begin{array}{c}-0.00314 \\
(-0.55)\end{array}$ & $\begin{array}{c}-0.00623 \\
(-1.06)\end{array}$ & $\begin{array}{c}-0.00739 \\
(-1.30)\end{array}$ \\
\hline housing wealth & & & \\
\hline home owner & $\begin{array}{c}0.00486 \\
(1.03)\end{array}$ & $\begin{array}{c}0.00345 \\
(0.76)\end{array}$ & $\begin{array}{c}0.00759 \\
(1.60)\end{array}$ \\
\hline mortgagee & $\begin{array}{c}0.00833 \\
(1.17)\end{array}$ & $\begin{array}{c}0.00991 \\
(1.42)\end{array}$ & $\begin{array}{c}0.0132+ \\
(1.72)\end{array}$ \\
\hline financial strength & & & \\
\hline positive saving & $\begin{array}{c}-0.000675 \\
(-0.15)\end{array}$ & $\begin{array}{c}0.00416 \\
(0.77)\end{array}$ & $\begin{array}{c}0.0123^{*} \\
(2.08)\end{array}$ \\
\hline risky assets owner & $\begin{array}{c}0.0270^{* *} \\
(2.89)\end{array}$ & $\begin{array}{c}0.0182+ \\
(1.88)\end{array}$ & $\begin{array}{c}0.0150 \\
(1.52)\end{array}$ \\
\hline $\begin{array}{l}\text { sellers' local availability } \\
\text { medium city }(20,000 \text { to } 40,000)\end{array}$ & $\begin{array}{c}0.00633 \\
(1.01)\end{array}$ & $\begin{array}{c}0.00387 \\
(0.56)\end{array}$ & $\begin{array}{c}0.00379 \\
(0.54)\end{array}$ \\
\hline large city $(40,000$ to 500,000$)$ & $\begin{array}{c}0.00612 \\
(1.24)\end{array}$ & $\begin{array}{c}-0.00561 \\
(-1.07)\end{array}$ & $\begin{array}{c}-0.000357 \\
(-0.07)\end{array}$ \\
\hline big city $(500,000+)$ & $\begin{array}{c}0.00320 \\
(0.39)\end{array}$ & $\begin{array}{c}-0.0138+ \\
(-1.86)\end{array}$ & $\begin{array}{c}0.00403 \\
(0.44)\end{array}$ \\
\hline constant & $\begin{array}{c}-0.181^{* * *} \\
(-4.42)\end{array}$ & $\begin{array}{c}-0.118^{* *} \\
(-3.09) \\
\end{array}$ & $\begin{array}{l}-0.101^{*} \\
(-2.44)\end{array}$ \\
\hline $\begin{array}{l}\text { Number of obs } \\
\text { R-squared }\end{array}$ & $\begin{array}{c}5,347 \\
0.0471 \\
F(30,5316)=3.31^{* * *}\end{array}$ & $\begin{array}{c}5,158 \\
0.0286 \\
F(30,5127)=3.72^{* * *}\end{array}$ & $\begin{array}{c}4,810 \\
0.0227 \\
F(30,4779)=3.51^{* * *}\end{array}$ \\
\hline Exclusion restrictions tests: & & & \\
\hline T1: saving=risky assets $=0$ & $\mathrm{~F}(2,5316)=4.20^{* * *}$ & $F(2,5127)=2.09$ & $F(2,4779)=4.23^{*}$ \\
\hline T2: medium $=$ large $=$ big city $=0$ & $F(3,5316)=0.60$ & $F(3,5127)=2.07$ & $F(3,4779)=0.21$ \\
\hline T3: T1\&T2 & $F(5,5316)=2.14+$ & $F(5,5127)=2.06 *$ & $F(5,4779)=1.75$ \\
\hline
\end{tabular}

${ }^{1}$ See Table $9 .{ }^{+} \mathrm{p}<0.10,{ }^{*} \mathrm{p}<0.05,{ }^{* *} \mathrm{p}<0.01,{ }^{* * *} \mathrm{p}<0.001$. 
Table 13. Average marginal effects (probit estimates at age $=45$ ); only statistically significant effects ${ }^{1}$

\begin{tabular}{|c|c|c|c|c|c|c|}
\hline & female & $\begin{array}{l}\text { positive } \\
\text { saving }\end{array}$ & $\begin{array}{l}\text { risky asset } \\
\text { holder }\end{array}$ & $\begin{array}{l}\text { medium city } \\
(20,000 \text { to } \\
40,000 \\
\text { inhabitants) }\end{array}$ & $\begin{array}{l}\text { large city } \\
(40,000 \text { to } \\
500,000 \\
\text { inhabitants) }\end{array}$ & $\begin{array}{l}\text { big city } \\
(500,000+ \\
\text { inhabitants })\end{array}$ \\
\hline & \multicolumn{6}{|c|}{2010 (Obs = 5347) } \\
\hline PENS & $-0.06 * * *$ & $0.02 *$ & $0.07 * * *$ & $-0.05^{* * *}$ & $-0.03 *$ & $-0.07 * * *$ \\
\hline PIPs & $-0.02 * * *$ & $0.04 * *$ & & $-0.03^{*}$ & $-0.03^{* * *}$ & $-0.04 * *$ \\
\hline - PIPCS & & $0.01+$ & & $-0.02+$ & $-0.02 * *$ & $-0.02^{*}$ \\
\hline - PIPNCS & $-0.02 *$ & $0.03 * * *$ & & & & $-0.02+$ \\
\hline \multirow[t]{2}{*}{ FPA } & $-0.01 * *$ & - & $0.02 * *$ & 0.01 & - & - \\
\hline & \multicolumn{6}{|c|}{2012 (Obs = 5158) } \\
\hline PENS & $-0.05^{* * *}$ & & $0.07 * * *$ & $-0.04 *$ & & \\
\hline PIPs & $-0.02^{* * *}$ & & & $-0.03^{* * *}$ & -0.02 & $-0.04 * * *$ \\
\hline$-P I P C S$ & $-0.02 *$ & & & & & \\
\hline - PIPNCS & & & $0.02+$ & $-0.03^{* *}$ & $-0.02 * *$ & $-0.04 * *$ \\
\hline \multirow[t]{2}{*}{ FPAs } & $-0.01+$ & & $0.01+$ & - & & $-0.02^{*}$ \\
\hline & \multicolumn{6}{|c|}{$2014($ Obs = 4810) } \\
\hline PENS & $-0.06 * * *$ & $0.03 *$ & $0.06 * * *$ & & $-0.06 * * *$ & $-0.09 * * *$ \\
\hline PIPs & $-0.03 * * *$ & $0.03 *$ & $0.04 * * *$ & $-0.03+$ & $-0.05 * * *$ & $-0.07 * * *$ \\
\hline - PIPCS & $-0.03^{* * *}$ & $0.02 * *$ & & $-0.02+$ & $-0.03 * *$ & $-0.04 * *$ \\
\hline - PIPNCS & & & $0.03 * *$ & & $-0.03 * *$ & $-0.02+$ \\
\hline FPAs & $-0.01 *$ & $0.01^{*}$ & & - & - & - \\
\hline
\end{tabular}


Table 14. Subscription rate to any private pension fund (PENS) and financial literacy. Cross section LPM estimates (samples out of balanced panel) ${ }^{1}$

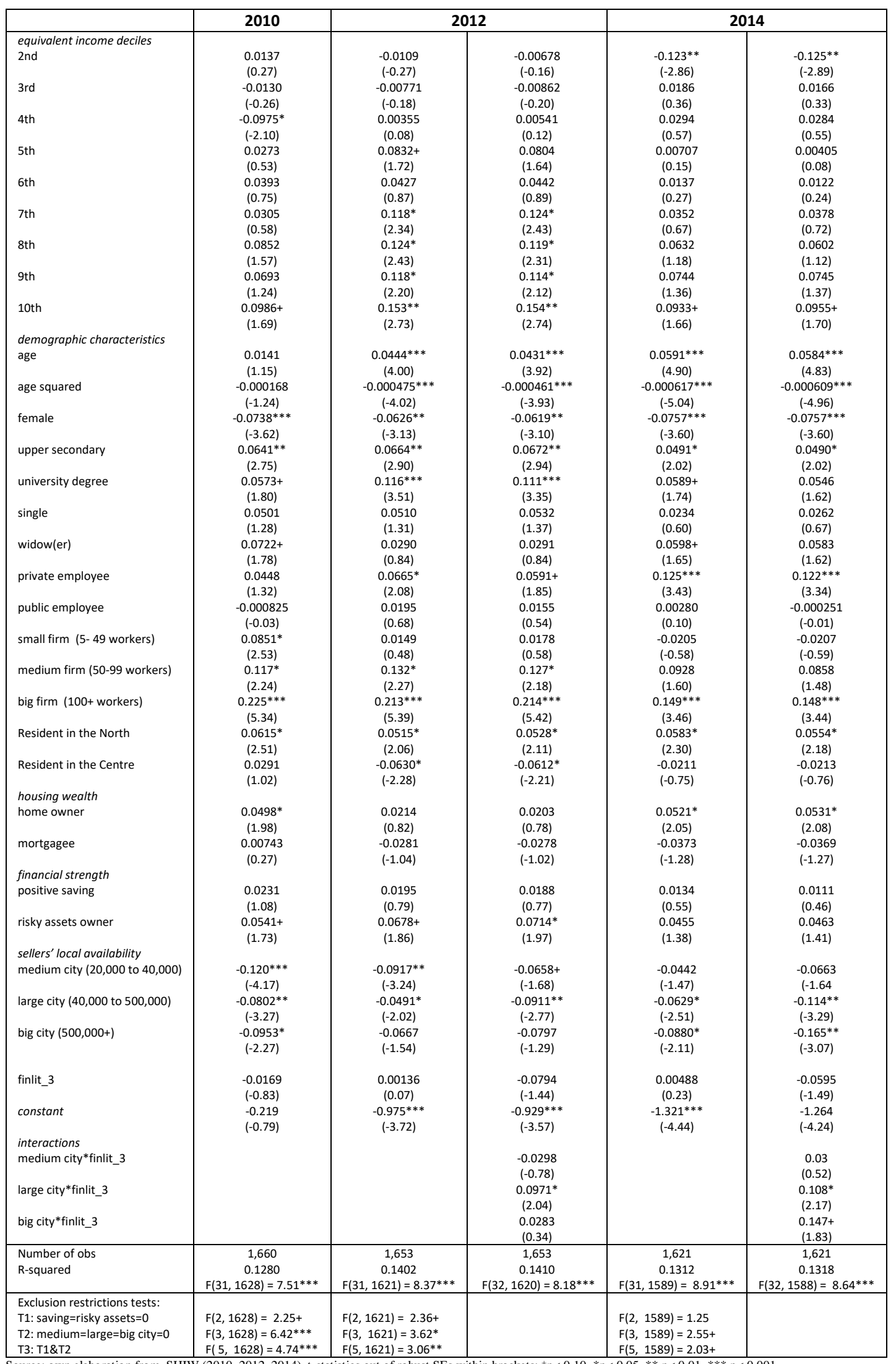

Source: own elaboration from SHIW $(2010,2012,2014)$. $t$-statistics out of robust SEs within brackets; ${ }^{*} p<0.10, * p<0.05, * * p<0.01, * * * p<0.001$.

125 to 65 years old employed household heads. Reference categories: first decile of equivalent per household income, male, up to lower secondary degree, married, self-employed, micro firm (1-4 workers), residence in a small city (up to 20,000 inhabitants) and in the South and Inlands, no home ownership, no mortgage, no saving, no risky assets ownership, less than three correct answers by household heads in the 2010 wave of the balanced panel. The table includes additional estimates for waves with statistically significant interactions of finlit_3 with city size categorical variables. 
Table 15. Subscription rate to PIPs. Cross section LPM estimates (samples out of balanced panel) ${ }^{1}$

\begin{tabular}{|c|c|c|c|c|}
\hline \multirow[b]{2}{*}{ equivalent income deciles } & \multirow[t]{2}{*}{2010} & \multicolumn{2}{|c|}{2012} & \multirow[t]{2}{*}{2014} \\
\hline & & & & \\
\hline 2nd & $\begin{array}{l}0.0418 \\
(1.45)\end{array}$ & $\begin{array}{l}0.0141 \\
(0.77)\end{array}$ & $\begin{array}{l}0.0168 \\
(0.90)\end{array}$ & $\begin{array}{c}-0.0668^{*} \\
(-2.26)\end{array}$ \\
\hline $3 r d$ & $\begin{array}{l}0.0117 \\
(0.43)\end{array}$ & $\begin{array}{c}0.0419+ \\
(1.81)\end{array}$ & $\begin{array}{l}0.0419+ \\
(1.82)\end{array}$ & $\begin{array}{c}-0.0342 \\
(-1.06)\end{array}$ \\
\hline 4th & $\begin{array}{l}-0.0225 \\
(-0.89)\end{array}$ & $\begin{array}{l}0.0198 \\
(0.90)\end{array}$ & $\begin{array}{l}0.0220 \\
(0.99)\end{array}$ & $\begin{array}{c}-0.0274 \\
(-0.82)\end{array}$ \\
\hline 5 th & $\begin{array}{l}0.0665^{*} \\
(2.02)\end{array}$ & $\begin{array}{c}0.0831^{* *} \\
(2.76)\end{array}$ & $\begin{array}{l}0.0822^{* *} \\
(2.72)\end{array}$ & $\begin{array}{c}-0.00767 \\
(-0.22)\end{array}$ \\
\hline 6th & $\begin{array}{l}0.0480 \\
(1.48)\end{array}$ & $\begin{array}{l}0.0265 \\
(1.01)\end{array}$ & $\begin{array}{l}0.0284 \\
(1.08)\end{array}$ & $\begin{array}{c}0.00558 \\
(0.15)\end{array}$ \\
\hline 7th & $\begin{array}{l}0.0335 \\
(1.06)\end{array}$ & $\begin{array}{l}0.106 * * \\
(3.23)\end{array}$ & $\begin{array}{l}0.108^{* *} \\
(3.28)\end{array}$ & $\begin{array}{l}0.0118 \\
(0.30)\end{array}$ \\
\hline 8th & $\begin{array}{l}0.0706^{*} \\
(2.04)\end{array}$ & $\begin{array}{c}0.0615+ \\
(1.93)\end{array}$ & $\begin{array}{l}0.0603+ \\
(1.89)\end{array}$ & $\begin{array}{l}0.0133 \\
(0.34)\end{array}$ \\
\hline 9th & $\begin{array}{l}0.0580 \\
(1.60)\end{array}$ & $\begin{array}{c}0.0956^{* *} \\
(2.66)\end{array}$ & $\begin{array}{l}0.0953^{* *} \\
(2.65)\end{array}$ & $\begin{array}{l}0.0164 \\
(0.41)\end{array}$ \\
\hline $\begin{array}{l}\text { 10th } \\
\text { demographic characteristics }\end{array}$ & $\begin{array}{l}0.0496 \\
(1.29)\end{array}$ & $\begin{array}{l}0.101^{* *} \\
(2.66)\end{array}$ & $\begin{array}{l}0.103^{* *} \\
(2.72)\end{array}$ & $\begin{array}{l}0.0391 \\
(0.93)\end{array}$ \\
\hline age & $\begin{array}{c}-0.00169 \\
(-0.17)\end{array}$ & $\begin{array}{l}0.0191^{*} \\
(2.21)\end{array}$ & $\begin{array}{l}0.0188^{*} \\
(2.17)\end{array}$ & $\begin{array}{c}0.0284^{* *} \\
(3.19)\end{array}$ \\
\hline age squared & $\begin{array}{c}0.000000714 \\
(0.01)\end{array}$ & $\begin{array}{c}-0.000205^{*} \\
(-2.24)\end{array}$ & $\begin{array}{l}-0.000202^{*} \\
(-2.20)\end{array}$ & $\begin{array}{c}-0.000304^{* * *} \\
(-3.39)\end{array}$ \\
\hline female & $\begin{array}{c}-0.0519^{* * *} \\
(-3.30)\end{array}$ & $\begin{array}{c}-0.0459^{* *} \\
(-3.00)\end{array}$ & $\begin{array}{l}-0.0454^{* *} \\
-2.96)\end{array}$ & $\begin{array}{c}-0.0282+ \\
(-1.79)\end{array}$ \\
\hline upper secondary & $\begin{array}{c}0.0425^{*} \\
(2.35)\end{array}$ & $\begin{array}{c}0.0323+ \\
(1.89)\end{array}$ & $\begin{array}{l}0.0328+ \\
(1.92)\end{array}$ & $\begin{array}{l}0.0220 \\
(1.19)\end{array}$ \\
\hline university degree & $\begin{array}{l}0.0382 \\
(1.59)\end{array}$ & $\begin{array}{c}0.0482+ \\
(1.87)\end{array}$ & $\begin{array}{l}0.0468+ \\
(1.82)\end{array}$ & $\begin{array}{l}0.0245 \\
(0.96)\end{array}$ \\
\hline single & $\begin{array}{l}0.0301 \\
(0.94)\end{array}$ & $\begin{array}{l}0.0294 \\
(0.96)\end{array}$ & $\begin{array}{l}0.0296 \\
(0.97)\end{array}$ & $\begin{array}{l}0.0221 \\
(0.73)\end{array}$ \\
\hline widow(er) & $\begin{array}{c}-0.00611 \\
(-0.23)\end{array}$ & $\begin{array}{c}0.00265 \\
(0.10)\end{array}$ & $\begin{array}{l}0.00540 \\
(0.21)\end{array}$ & $\begin{array}{l}0.0123 \\
(0.50)\end{array}$ \\
\hline private employee & $\begin{array}{c}0.00272 \\
(0.10)\end{array}$ & $\begin{array}{l}0.0199 \\
(0.78)\end{array}$ & $\begin{array}{l}0.0180 \\
(0.70)\end{array}$ & $\begin{array}{l}0.0582^{*} \\
(2.23)\end{array}$ \\
\hline public employee & $\begin{array}{c}-0.0487^{*} \\
(-2.26)\end{array}$ & $\begin{array}{c}-0.0269 \\
(-1.23)\end{array}$ & $\begin{array}{c}-0.0284 \\
(-1.29)\end{array}$ & $\begin{array}{l}-0.0160 \\
(-0.80)\end{array}$ \\
\hline small firm (5- 49 workers) & $\begin{array}{l}0.0128 \\
(0.48)\end{array}$ & $\begin{array}{l}-0.0179 \\
(-0.77)\end{array}$ & $\begin{array}{l}-0.0162 \\
(-0.70)\end{array}$ & $\begin{array}{l}-0.0108 \\
(-0.42)\end{array}$ \\
\hline medium firm (50-99 workers) & $\begin{array}{l}0.0370 \\
(0.88)\end{array}$ & $\begin{array}{l}0.0532 \\
(1.12)\end{array}$ & $\begin{array}{l}0.0523 \\
(1.10)\end{array}$ & $\begin{array}{l}0.0238 \\
(0.54)\end{array}$ \\
\hline big firm (100+ workers) & $\begin{array}{l}0.0725^{*} \\
(2.12)\end{array}$ & $\begin{array}{c}0.0914^{* *} \\
(2.87)\end{array}$ & $\begin{array}{l}0.0930 * * \\
(2.92)\end{array}$ & $\begin{array}{c}0.0584+ \\
(1.83)\end{array}$ \\
\hline Resident in the North & $\begin{array}{c}0.0554^{* *} \\
(3.10)\end{array}$ & $\begin{array}{c}0.0364+ \\
(1.92)\end{array}$ & $\begin{array}{l}0.0385 * \\
(2.03)\end{array}$ & $\begin{array}{l}0.0455^{*} \\
(2.45)\end{array}$ \\
\hline $\begin{array}{l}\text { Resident in the Centre } \\
\text { housing wealth }\end{array}$ & $\begin{array}{l}0.0120 \\
(0.56)\end{array}$ & $\begin{array}{l}-0.0290 \\
(-1.45)\end{array}$ & $\begin{array}{l}-0.0277 \\
(-1.39)\end{array}$ & $\begin{array}{l}0.0182 \\
(0.89)\end{array}$ \\
\hline home owner & $\begin{array}{l}0.0383^{*} \\
(1.99)\end{array}$ & $\begin{array}{c}0.00731 \\
(0.37)\end{array}$ & $\begin{array}{l}0.00727 \\
(0.36)\end{array}$ & $\begin{array}{l}0.0431^{*} \\
(2.34)\end{array}$ \\
\hline mortgagee & $\begin{array}{c}-0.00454 \\
(-0.20)\end{array}$ & $\begin{array}{c}-0.00347 \\
(-0.16)\end{array}$ & $\begin{array}{l}-0.00413 \\
(-0.20)\end{array}$ & $\begin{array}{l}-0.0238 \\
(-1.04)\end{array}$ \\
\hline $\begin{array}{l}\text { financial strength } \\
\text { positive saving }\end{array}$ & $\begin{array}{c}0.0285+ \\
(1.71)\end{array}$ & $\begin{array}{l}0.0225 \\
(1.13)\end{array}$ & $\begin{array}{l}0.0218 \\
(1.10)\end{array}$ & $\begin{array}{l}0.0191 \\
(1.02)\end{array}$ \\
\hline $\begin{array}{l}\text { risky asset owner } \\
\text { sellers' local availability }\end{array}$ & $\begin{array}{c}0.0174 \\
(0.70)\end{array}$ & $\begin{array}{c}0.0292 \\
(1.00)\end{array}$ & $\begin{array}{l}0.0302 \\
(1.03)\end{array}$ & $\begin{array}{l}0.0433 \\
(1.61)\end{array}$ \\
\hline medium city $(20,000$ to 40,000$)$ & $\begin{array}{c}-0.0929 * * * \\
(-4.22)\end{array}$ & $\begin{array}{c}-0.0690 * * \\
(-3.19)\end{array}$ & $\begin{array}{c}-0.0291 \\
(-0.97)\end{array}$ & $\begin{array}{c}-0.0494^{*} \\
(-2.11)\end{array}$ \\
\hline large city $(40,000$ to 500,000$)$ & $\begin{array}{c}-0.0654^{* * *} \\
(-3.34)\end{array}$ & $\begin{array}{c}-0.0568^{* *} \\
(-2.91)\end{array}$ & $\begin{array}{c}-0.0431+ \\
(-1.70)\end{array}$ & $\begin{array}{c}-0.0724 * * * \\
(-3.64)\end{array}$ \\
\hline big city $(500,000+)$ & $\begin{array}{c}-0.0330 \\
(-0.91)\end{array}$ & $\begin{array}{c}-0.0829^{* *} \\
(-2.77)\end{array}$ & $\begin{array}{l}-0.0583 \\
(-1.35)\end{array}$ & $\begin{array}{c}-0.0654^{*} \\
(-2.02)\end{array}$ \\
\hline finlit_3 & $\begin{array}{r}-0.0147 \\
(-0.95)\end{array}$ & $\begin{array}{c}-0.00937 \\
(-0.60)\end{array}$ & $\begin{array}{l}0.0219 \\
(0.71)\end{array}$ & $\begin{array}{c}-0.0292+ \\
(-1.82)\end{array}$ \\
\hline constant & $\begin{array}{l}0.119 \\
(0.52)\end{array}$ & $\begin{array}{c}-0.391+ \\
(-1.96)\end{array}$ & $\begin{array}{c}-0.402^{*} \\
(-1.99)\end{array}$ & $\begin{array}{c}-0.590 * * \\
(-2.73)\end{array}$ \\
\hline $\begin{array}{l}\text { interactions } \\
\text { medium city*finlit_3 } \\
\text { large city*finlit_3 } \\
\text { big city*finlit_3 }\end{array}$ & & & $\begin{array}{l}-0.0937^{*} \\
(-2.22) \\
-0.0237 \\
(-0.63) \\
-0.0455 \\
(-0.79) \\
\end{array}$ & \\
\hline $\begin{array}{l}\text { Number of obs } \\
\text { R-squared }\end{array}$ & $\begin{array}{c}1,660 \\
0.0742 \\
\mathrm{~F}(31,1628)=3.70^{* * *}\end{array}$ & $\begin{array}{c}1,653 \\
0.0782 \\
F(31,1621)=5.05^{* * *}\end{array}$ & $\begin{array}{c}1,653 \\
0.0810 \\
F(34,1618)=4.59\end{array}$ & $\begin{array}{c}1,621 \\
0.0810 \\
F(31,1589)=4.33^{* * *}\end{array}$ \\
\hline $\begin{array}{l}\text { Exclusion restrictions tests: } \\
\text { T1: } \text { saving=risky assets }=0 \\
\text { T2: } \text { medium=large =big city=0 } \\
\text { T3: } \mathrm{T} 1 \& \mathrm{~T} 2\end{array}$ & $\begin{array}{l}F(2,1628)=1.82 \\
F(3,1628)=6.51^{* * *} \\
F(5,1628)=4.48^{* * *}\end{array}$ & $\begin{array}{l}F(2,1621)=1.32 \\
F(3,1621)=4.51^{*} \\
F(5,1621)=3.13^{*}\end{array}$ & & $\begin{array}{l}F(2,1589)=2.20 \\
F(3,1589)=4.44^{* *} \\
F(5,1589)=3.55^{* *}\end{array}$ \\
\hline
\end{tabular}

${ }^{1}$ See Table 14. ${ }^{+} \mathrm{p}<0.10,{ }^{*} \mathrm{p}<0.05, * * \mathrm{p}<0.01, * * * \mathrm{p}<0.001$. 


\begin{tabular}{|c|c|c|c|c|c|c|c|c|c|}
\hline \multirow[b]{3}{*}{ eqv. income deciles } & \multicolumn{3}{|c|}{2010} & \multicolumn{3}{|c|}{2012} & \multicolumn{3}{|c|}{2014} \\
\hline & \multicolumn{2}{|c|}{ PIPCs } & \multirow{3}{*}{$\begin{array}{c}\text { PIPNCS } \\
0.0176 \\
(0.79)\end{array}$} & \multicolumn{2}{|c|}{ PIPCs } & \multirow{3}{*}{$\begin{array}{c}\text { PIPNCs } \\
0.0199 \\
(1.32)\end{array}$} & \multicolumn{2}{|c|}{ PIPCs } & \multirow{3}{*}{$\begin{array}{c}\text { PIPNCS } \\
-0.0368 \\
(-1.63)\end{array}$} \\
\hline & & & & & & & & & \\
\hline 2nd & $\begin{array}{l}0.0242 \\
(1.33)\end{array}$ & $\begin{array}{l}0.0216 \\
(1.20)\end{array}$ & & $\begin{array}{l}-0.00578 \\
(-0.56)\end{array}$ & $\begin{array}{l}-0.00543 \\
(-0.52)\end{array}$ & & $\begin{array}{c}-0.0300 \\
(-1.62)\end{array}$ & $\begin{array}{c}-0.0295 \\
(-1.59)\end{array}$ & \\
\hline $3 \mathrm{rd}$ & $\begin{array}{l}0.0144 \\
(0.77)\end{array}$ & $\begin{array}{l}0.0129 \\
(0.69)\end{array}$ & $\begin{array}{c}-0.00270 \\
(-0.13)\end{array}$ & $\begin{array}{c}0.00572 \\
(0.38)\end{array}$ & $\begin{array}{c}0.00539 \\
(0.36)\end{array}$ & $\begin{array}{c}0.0362^{*} \\
(1.96)\end{array}$ & $\begin{array}{l}-0.0202 \\
(-0.98)\end{array}$ & $\begin{array}{r}-0.0210 \\
(-1.02)\end{array}$ & $\begin{array}{c}-0.0141 \\
(-0.57)\end{array}$ \\
\hline 4th & $\begin{array}{c}-0.00964 \\
(-0.72)\end{array}$ & $\begin{array}{c}-0.0101 \\
(-0.76)\end{array}$ & $\begin{array}{c}-0.0128 \\
(-0.60)\end{array}$ & $\begin{array}{c}-0.00675 \\
(-0.45)\end{array}$ & $\begin{array}{c}-0.00640 \\
(-0.43)\end{array}$ & $\begin{array}{l}0.0266 \\
(1.60)\end{array}$ & $\begin{array}{l}-0.0114 \\
(-0.49)\end{array}$ & $\begin{array}{c}-0.0114 \\
(-0.49)\end{array}$ & $\begin{array}{l}-0.0160 \\
(-0.67)\end{array}$ \\
\hline 5th & $\begin{array}{c}0.0199 \\
(0.98)\end{array}$ & $\begin{array}{l}0.0208 \\
(1.03)\end{array}$ & $\begin{array}{c}0.0466+ \\
(1.72)\end{array}$ & $\begin{array}{l}0.0399 \\
(1.63)\end{array}$ & $\begin{array}{l}0.0385 \\
(1.56)\end{array}$ & $\begin{array}{c}0.0432^{*} \\
(2.19)\end{array}$ & $\begin{array}{c}-0.00555 \\
(-0.25)\end{array}$ & $\begin{array}{c}-0.00683 \\
(-0.30)\end{array}$ & $\begin{array}{c}-0.00212 \\
(-0.08)\end{array}$ \\
\hline 6th & $\begin{array}{c}0.000244 \\
(0.01)\end{array}$ & $\begin{array}{c}-0.00356 \\
(-0.20)\end{array}$ & $\begin{array}{c}0.0478+ \\
(1.68)\end{array}$ & $\begin{array}{c}0.00106 \\
(0.06)\end{array}$ & $\begin{array}{c}0.00124 \\
(0.07)\end{array}$ & $\begin{array}{l}0.0255 \\
(1.26)\end{array}$ & $\begin{array}{c}-0.00522 \\
(-0.21)\end{array}$ & $\begin{array}{l}-0.00476 \\
(-0.19)\end{array}$ & $\begin{array}{l}0.0108 \\
(0.37)\end{array}$ \\
\hline 7th & $\begin{array}{l}0.0313 \\
(1.54)\end{array}$ & $\begin{array}{l}0.0280 \\
(1.38)\end{array}$ & $\begin{array}{c}0.00218 \\
(0.09)\end{array}$ & $\begin{array}{l}0.0146 \\
(0.79)\end{array}$ & $\begin{array}{l}0.0141 \\
(0.76)\end{array}$ & $\begin{array}{c}0.0909^{* *} \\
(3.26)\end{array}$ & $\begin{array}{c}-0.0124 \\
(-0.50)\end{array}$ & $\begin{array}{c}-0.0117 \\
(-0.47)\end{array}$ & $\begin{array}{l}0.0241 \\
(0.77)\end{array}$ \\
\hline 8th & $\begin{array}{c}0.0606 * \\
(2.48)\end{array}$ & $\begin{array}{c}0.0575^{*} \\
(2.35)\end{array}$ & $\begin{array}{c}0.00995 \\
(0.39)\end{array}$ & $\begin{array}{l}0.0407 \\
(1.62)\end{array}$ & $\begin{array}{l}0.0403 \\
(1.61)\end{array}$ & $\begin{array}{l}0.0208 \\
(0.99)\end{array}$ & $\begin{array}{c}-0.00536 \\
(-0.21)\end{array}$ & $\begin{array}{c}-0.00505 \\
(-0.19)\end{array}$ & $\begin{array}{l}0.0186 \\
(0.65)\end{array}$ \\
\hline 9th & $\begin{array}{l}0.0263 \\
(1.13)\end{array}$ & $\begin{array}{l}0.0256 \\
(1.11)\end{array}$ & $\begin{array}{l}0.0317 \\
(1.11)\end{array}$ & $\begin{array}{l}0.0383 \\
(1.57)\end{array}$ & $\begin{array}{l}0.0381 \\
(1.57)\end{array}$ & $\begin{array}{l}0.0573^{*} \\
(2.03)\end{array}$ & $\begin{array}{l}-0.0189 \\
(-0.78)\end{array}$ & $\begin{array}{c}-0.0175 \\
(-0.72)\end{array}$ & $\begin{array}{l}0.0353 \\
(1.07)\end{array}$ \\
\hline $\begin{array}{l}\text { 10th } \\
\text { demographic chrs }\end{array}$ & $\begin{array}{l}0.0285 \\
(1.10)\end{array}$ & $\begin{array}{l}0.0289 \\
(1.10)\end{array}$ & $\begin{array}{l}0.0210 \\
(0.71)\end{array}$ & $\begin{array}{l}0.0272 \\
(1.07)\end{array}$ & $\begin{array}{l}0.0279 \\
(1.10)\end{array}$ & $\begin{array}{c}0.0733^{*} \\
(2.47)\end{array}$ & $\begin{array}{c}-0.0259 \\
(-1.02)\end{array}$ & $\begin{array}{c}-0.0246 \\
(-0.97)\end{array}$ & $\begin{array}{c}0.0650+ \\
(1.92)\end{array}$ \\
\hline age & $\begin{array}{l}-0.0113 \\
(-1.56)\end{array}$ & $\begin{array}{l}-0.0116 \\
(-1.59)\end{array}$ & $\begin{array}{c}0.00957 \\
(1.24)\end{array}$ & $\begin{array}{c}0.00984+ \\
(1.80)\end{array}$ & $\begin{array}{c}0.00966+ \\
(1.75)\end{array}$ & $\begin{array}{c}0.00924 \\
(1.32)\end{array}$ & $\begin{array}{c}0.0104+ \\
(1.70)\end{array}$ & $\begin{array}{c}0.0101+ \\
(1.65)\end{array}$ & $\begin{array}{c}0.0180 * * \\
(2.69)\end{array}$ \\
\hline age squared & $\begin{array}{c}0.000114 \\
(1.47)\end{array}$ & $\begin{array}{c}0.000118 \\
(1.51)\end{array}$ & $\begin{array}{c}-0.000113 \\
(-1.33)\end{array}$ & $\begin{array}{c}-0.0000994+ \\
(-1.74)\end{array}$ & $\begin{array}{c}-0.0000978+ \\
(-1.70)\end{array}$ & $\begin{array}{c}-0.000106 \\
(-1.41)\end{array}$ & $\begin{array}{c}-0.000110+ \\
(-1.81)\end{array}$ & $\begin{array}{c}-0.000107+ \\
(-1.75)\end{array}$ & $\begin{array}{c}-0.000194^{* *} \\
(-2.84)\end{array}$ \\
\hline female & $\begin{array}{c}-0.0126 \\
(-1.14)\end{array}$ & $\begin{array}{c}-0.0122 \\
(-1.10)\end{array}$ & $\begin{array}{c}-0.0393^{* *} \\
(-3.28)\end{array}$ & $\begin{array}{c}-0.0230^{*} \\
(-2.14)\end{array}$ & $\begin{array}{c}-0.0226^{*} \\
(-2.10)\end{array}$ & $\begin{array}{c}-0.0230+ \\
(-1.95)\end{array}$ & $\begin{array}{c}-0.0312^{* *} \\
(-2.77)\end{array}$ & $\begin{array}{c}-0.0313^{* *} \\
(-2.78)\end{array}$ & $\begin{array}{c}0.00305 \\
(0.26)\end{array}$ \\
\hline upper sec & $\begin{array}{c}0.0297^{*} \\
(2.32)\end{array}$ & $\begin{array}{c}0.0300^{*} \\
(2.35)\end{array}$ & $\begin{array}{c}0.0129 \\
(0.94)\end{array}$ & $\begin{array}{c}0.0298^{*} \\
(2.40)\end{array}$ & $\begin{array}{c}0.0299^{*} \\
(2.42)\end{array}$ & $\begin{array}{c}0.00255 \\
(0.20)\end{array}$ & $\begin{array}{l}0.0161 \\
(1.17)\end{array}$ & $\begin{array}{c}0.0156 \\
(1.15)\end{array}$ & $\begin{array}{c}0.00600 \\
(0.45)\end{array}$ \\
\hline university & $\begin{array}{c}0.00376 \\
(0.24)\end{array}$ & $\begin{array}{c}0.00359 \\
(0.23)\end{array}$ & $\begin{array}{c}0.0345+ \\
(1.79)\end{array}$ & $\begin{array}{l}0.0129 \\
(0.75)\end{array}$ & $\begin{array}{l}0.0130 \\
(0.75)\end{array}$ & $\begin{array}{c}0.0353+ \\
(1.71)\end{array}$ & $\begin{array}{l}0.0132 \\
(0.72)\end{array}$ & $\begin{array}{l}0.0121 \\
(0.66)\end{array}$ & $\begin{array}{l}0.0112 \\
(0.59)\end{array}$ \\
\hline single & $\begin{array}{c}-0.0159 \\
(-0.83)\end{array}$ & $\begin{array}{c}-0.0148 \\
(-0.77)\end{array}$ & $\begin{array}{c}0.0459+ \\
(1.68)\end{array}$ & $\begin{array}{c}-0.0110 \\
(-0.64)\end{array}$ & $\begin{array}{l}-0.0102 \\
(-0.59)\end{array}$ & $\begin{array}{l}0.0404 \\
(1.52)\end{array}$ & $\begin{array}{c}0.00576 \\
(0.29)\end{array}$ & $\begin{array}{c}0.00742 \\
(0.38)\end{array}$ & $\begin{array}{l}0.0163 \\
(0.68)\end{array}$ \\
\hline widow(er) & $\begin{array}{l}-0.0141 \\
(-0.78)\end{array}$ & $\begin{array}{l}-0.0111 \\
(-0.62)\end{array}$ & $\begin{array}{c}0.00795 \\
(0.40)\end{array}$ & $\begin{array}{c}-0.0379 * * \\
(-3.14)\end{array}$ & $\begin{array}{c}-0.0354^{* *} \\
(-2.95)\end{array}$ & $\begin{array}{c}0.0406+ \\
(1.72)\end{array}$ & $\begin{array}{l}-0.0135 \\
(-0.97)\end{array}$ & $\begin{array}{c}-0.0141 \\
(-1.00)\end{array}$ & $\begin{array}{c}0.0259 \\
(1.22)\end{array}$ \\
\hline private employee & $\begin{array}{l}0.0109 \\
(0.90)\end{array}$ & $\begin{array}{l}0.0120 \\
(0.99)\end{array}$ & $\begin{array}{c}-0.00816 \\
(-0.32)\end{array}$ & $\begin{array}{l}0.0252 \\
(1.60)\end{array}$ & $\begin{array}{c}0.0247 \\
(1.55)\end{array}$ & $\begin{array}{c}-0.00530 \\
(-0.25)\end{array}$ & $\begin{array}{c}0.0463^{* *} \\
(3.21)\end{array}$ & $\begin{array}{c}0.0456^{* *} \\
(3.16)\end{array}$ & $\begin{array}{l}0.0119 \\
(0.54)\end{array}$ \\
\hline public employee & $\begin{array}{c}0.00818 \\
(0.89)\end{array}$ & $\begin{array}{c}0.00847 \\
(0.93)\end{array}$ & $\begin{array}{c}-0.0568^{* *} \\
(-2.87)\end{array}$ & $\begin{array}{c}-0.00564 \\
(-0.52)\end{array}$ & $\begin{array}{c}-0.00664 \\
(-0.60)\end{array}$ & $\begin{array}{c}-0.0213 \\
(-1.09)\end{array}$ & $\begin{array}{c}0.0187+ \\
(1.94)\end{array}$ & $\begin{array}{c}0.0179+ \\
(1.85)\end{array}$ & $\begin{array}{c}-0.0348+ \\
(-1.95)\end{array}$ \\
\hline small firm (5- 49) & $\begin{array}{c}0.0443^{* *} \\
(2.98)\end{array}$ & $\begin{array}{c}0.0448^{* *} \\
(3.00)\end{array}$ & $\begin{array}{c}-0.0315 \\
(-1.40)\end{array}$ & $\begin{array}{c}-0.00170 \\
(-0.11)\end{array}$ & $\begin{array}{c}-0.000785 \\
(-0.05)\end{array}$ & $\begin{array}{l}-0.0162 \\
(-0.90)\end{array}$ & $\begin{array}{c}-0.00656 \\
(-0.40)\end{array}$ & $\begin{array}{c}-0.00701 \\
(-0.43)\end{array}$ & $\begin{array}{c}-0.00423 \\
(-0.21)\end{array}$ \\
\hline medium firm (50-99) & $\begin{array}{c}0.0857^{* *} \\
(2.74)\end{array}$ & $\begin{array}{c}0.0822^{* *} \\
(2.68)\end{array}$ & $\begin{array}{l}-0.0487 \\
(-1.61)\end{array}$ & $\begin{array}{c}0.00768 \\
(0.25)\end{array}$ & $\begin{array}{c}0.00823 \\
(0.27)\end{array}$ & $\begin{array}{l}0.0455 \\
(1.16)\end{array}$ & $\begin{array}{l}0.0187 \\
(0.61)\end{array}$ & $\begin{array}{l}0.0169 \\
(0.55)\end{array}$ & $\begin{array}{l}0.00509 \\
(0.15)\end{array}$ \\
\hline big firm $(100+)$ & $\begin{array}{c}0.121^{* * *} \\
(4.96)\end{array}$ & $\begin{array}{c}0.123^{* * *} \\
(5.02)\end{array}$ & $\begin{array}{c}-0.0486+ \\
(-1.89)\end{array}$ & $\begin{array}{c}0.0987^{* * *} \\
(4.02)\end{array}$ & $\begin{array}{c}0.100^{* * *} \\
(4.09)\end{array}$ & $\begin{array}{c}-0.00726 \\
(-0.32)\end{array}$ & $\begin{array}{c}0.104 * * * \\
(4.26)\end{array}$ & $\begin{array}{c}0.103^{* * *} \\
(4.23)\end{array}$ & $\begin{array}{c}-0.0455^{*} \\
(-2.04)\end{array}$ \\
\hline Resident in the North & $\begin{array}{l}0.0139 \\
(1.16)\end{array}$ & $\begin{array}{l}0.0163 \\
(1.36)\end{array}$ & $\begin{array}{c}0.0415^{* *} \\
(3.03)\end{array}$ & $\begin{array}{c}0.0299 * * \\
(2.69)\end{array}$ & $\begin{array}{c}0.0312^{* *} \\
(2.80)\end{array}$ & $\begin{array}{c}0.00657 \\
(0.41)\end{array}$ & $\begin{array}{c}0.0482^{* * *} \\
(3.78)\end{array}$ & $\begin{array}{c}0.0466^{* * *} \\
(3.60)\end{array}$ & $\begin{array}{l}-0.00271 \\
(-0.19)\end{array}$ \\
\hline $\begin{array}{l}\text { Resident in the } \\
\text { Centre }\end{array}$ & $\begin{array}{c}0.00346 \\
(0.22)\end{array}$ & $\begin{array}{l}0.00525 \\
(0.34)\end{array}$ & $\begin{array}{l}0.00856 \\
(0.54)\end{array}$ & $\begin{array}{l}0.00802 \\
(0.60)\end{array}$ & $\begin{array}{l}0.00930 \\
(0.70)\end{array}$ & $\begin{array}{c}-0.0371^{*} \\
(-2.35)\end{array}$ & $\begin{array}{l}0.0206 \\
(1.53)\end{array}$ & $\begin{array}{l}0.0204 \\
(1.51)\end{array}$ & $\begin{array}{c}-0.00241 \\
(-0.15)\end{array}$ \\
\hline housing wealth & & & & & & & & & \\
\hline home owner & $\begin{array}{c}0.0217+ \\
(1.73)\end{array}$ & $\begin{array}{l}0.0232+ \\
(1.85)\end{array}$ & $\begin{array}{l}0.0167 \\
(1.09)\end{array}$ & $\begin{array}{l}0.0138 \\
(1.09)\end{array}$ & $\begin{array}{l}0.0148 \\
(1.18)\end{array}$ & $\begin{array}{c}-0.00646 \\
(-0.40)\end{array}$ & $\begin{array}{c}0.0517 * * * \\
(3.99)\end{array}$ & $\begin{array}{c}0.0526 * * * \\
(4.03)\end{array}$ & $\begin{array}{c}-0.00860 \\
(-0.62)\end{array}$ \\
\hline mortgagee & $\begin{array}{c}0.00154 \\
(0.10)\end{array}$ & $\begin{array}{c}0.00134 \\
(0.08)\end{array}$ & $\begin{array}{c}-0.00608 \\
(-0.37)\end{array}$ & $\begin{array}{c}-0.00322 \\
(-0.20)\end{array}$ & $\begin{array}{c}-0.00343 \\
(-0.22)\end{array}$ & $\begin{array}{c}-0.000251 \\
(-0.02)\end{array}$ & $\begin{array}{c}-0.0326^{*} \\
(-2.07)\end{array}$ & $\begin{array}{c}-0.0323^{*} \\
(-2.05)\end{array}$ & $\begin{array}{l}0.00874 \\
(0.50)\end{array}$ \\
\hline $\begin{array}{l}\text { financial strength } \\
\text { positive saving }\end{array}$ & $\begin{array}{c}-0.00446 \\
(-0.39)\end{array}$ & $\begin{array}{c}-0.00427 \\
(-0.37)\end{array}$ & $\begin{array}{c}0.0330^{*} \\
(2.56)\end{array}$ & $\begin{array}{l}-0.00797 \\
(-0.61)\end{array}$ & $\begin{array}{c}-0.00864 \\
(-0.66)\end{array}$ & $\begin{array}{l}0.0304+ \\
(1.89)\end{array}$ & $\begin{array}{l}0.0127 \\
(0.94)\end{array}$ & $\begin{array}{l}0.0120 \\
(0.89)\end{array}$ & $\begin{array}{l}0.00640 \\
(0.46)\end{array}$ \\
\hline $\begin{array}{l}\text { risky asset owner } \\
\text { sellers' local avail. }\end{array}$ & $\begin{array}{c}0.0159 \\
(0.96)\end{array}$ & $\begin{array}{l}0.0138 \\
(0.82)\end{array}$ & $\begin{array}{c}0.00154 \\
(0.08)\end{array}$ & $\begin{array}{l}0.0172 \\
(0.82)\end{array}$ & $\begin{array}{l}0.0177 \\
(0.85)\end{array}$ & $\begin{array}{l}0.0120 \\
(0.55)\end{array}$ & $\begin{array}{l}0.0195 \\
(1.02)\end{array}$ & $\begin{array}{l}0.0195 \\
(1.02)\end{array}$ & $\begin{array}{l}0.0238 \\
(1.16)\end{array}$ \\
\hline $\begin{array}{l}\text { medium city }(20,000 \\
\text { to } 40,000)\end{array}$ & $\begin{array}{c}-0.0303^{*} \\
(-2.02)\end{array}$ & $\begin{array}{c}0.00389 \\
(0.18)\end{array}$ & $\begin{array}{c}-0.0625 * * * \\
(-3.66)\end{array}$ & $\begin{array}{c}-0.00861 \\
(-0.57)\end{array}$ & $\begin{array}{l}0.0179 \\
(0.83)\end{array}$ & $\begin{array}{c}-0.0604 * * * \\
(-3.66)\end{array}$ & $\begin{array}{c}-0.0370^{*} \\
(-2.12)\end{array}$ & $\begin{array}{c}-0.0530^{*} \\
(-1.96)\end{array}$ & $\begin{array}{c}-0.0124 \\
(-0.74)\end{array}$ \\
\hline $\begin{array}{l}\text { large city }(40,000 \text { to } \\
500,000)\end{array}$ & $\begin{array}{l}-0.0177 \\
(-1.34)\end{array}$ & $\begin{array}{l}0.00759 \\
(0.42)\end{array}$ & $\begin{array}{c}-0.0477^{* *} \\
(-3.03)\end{array}$ & $\begin{array}{c}-0.00125 \\
(-0.10)\end{array}$ & $\begin{array}{l}0.0186 \\
(1.08)\end{array}$ & $\begin{array}{c}-0.0555^{* * *} \\
(-3.49)\end{array}$ & $\begin{array}{c}-0.0473^{* *} \\
(-3.10)\end{array}$ & $\begin{array}{c}-0.0638^{* *} \\
(-2.62)\end{array}$ & $\begin{array}{c}-0.0252+ \\
(-1.80)\end{array}$ \\
\hline big city $(500,000+)$ & $\begin{array}{c}-0.00483 \\
(-0.20)\end{array}$ & $\begin{array}{c}0.00766 \\
(0.22)\end{array}$ & $\begin{array}{l}-0.0282 \\
(-0.96)\end{array}$ & $\begin{array}{c}-0.0249 \\
(-1.35)\end{array}$ & $\begin{array}{l}-0.0252 \\
(-1.05)\end{array}$ & $\begin{array}{c}-0.0580^{*} \\
(-2.27)\end{array}$ & $\begin{array}{c}-0.0467^{*} \\
(-2.18)\end{array}$ & $\begin{array}{c}-0.0869 * * \\
(-2.90)\end{array}$ & $\begin{array}{l}-0.0187 \\
(-0.73)\end{array}$ \\
\hline finlit_3 & $\begin{array}{c}-0.0203+ \\
(-1.91)\end{array}$ & $\begin{array}{l}0.0183 \\
(0.84)\end{array}$ & $\begin{array}{c}0.00562 \\
(0.47)\end{array}$ & $\begin{array}{c}-0.0173 \\
(-1.64)\end{array}$ & $\begin{array}{l}0.0119 \\
(0.60)\end{array}$ & $\begin{array}{c}0.00795 \\
(0.64)\end{array}$ & $\begin{array}{c}-0.0409 * * * \\
(-3.64)\end{array}$ & $\begin{array}{c}-0.0670^{* *} \\
(-2.61)\end{array}$ & $\begin{array}{l}0.0116 \\
(0.95)\end{array}$ \\
\hline constant & $\begin{array}{l}0.248 \\
(1.50)\end{array}$ & $\begin{array}{l}0.235 \\
(1.38)\end{array}$ & $\begin{array}{l}-0.129 \\
(-0.75)\end{array}$ & $\begin{array}{l}-0.251^{*} \\
(-1.98)\end{array}$ & $\begin{array}{l}-0.264^{*} \\
(-2.04)\end{array}$ & $\begin{array}{l}-0.140 \\
(-0.86)\end{array}$ & $\begin{array}{l}-0.232 \\
(-1.53)\end{array}$ & $\begin{array}{l}-0.210 \\
(-1.36)\end{array}$ & $\begin{array}{l}-0.357^{*} \\
(-2.23)\end{array}$ \\
\hline $\begin{array}{l}\text { interactions } \\
\text { medium city*finlit_3 }\end{array}$ & & $\begin{array}{c}-0.0735^{* *} \\
(-2.63)\end{array}$ & & & $\begin{array}{c}-0.0593^{*} \\
(-2.03)\end{array}$ & & & $\begin{array}{l}0.0325 \\
(0.94)\end{array}$ & \\
\hline large city*finlit_3 & & $\begin{array}{c}-0.0512+ \\
(-1.91)\end{array}$ & & & $\begin{array}{c}-0.0401 \\
(-1.59)\end{array}$ & & & $\begin{array}{l}0.0328 \\
(1.11)\end{array}$ & \\
\hline big city *finlit_3 & & $\begin{array}{l}-0.0255 \\
(-0.55) \\
\end{array}$ & & & $\begin{array}{c}-0.00105 \\
(-0.03)\end{array}$ & & & $\begin{array}{c}0.0768+ \\
(1.89)\end{array}$ & \\
\hline $\begin{array}{l}\text { Number of obs } \\
\text { R-squared }\end{array}$ & $\begin{array}{c}1,660 \\
0.0759 \\
F(31,628)= \\
2.51^{* * *}\end{array}$ & $\begin{array}{c}1,660 \\
0.0797 \\
F(34,1625) \\
=2.37^{* * *} \\
\end{array}$ & $\begin{array}{c}1,660 \\
0.0522 \\
F(31,1628) \\
=1.99^{* * *}\end{array}$ & $\begin{array}{c}1,653 \\
0.0773 \\
F(31,1621) \\
=2.47^{* * *} \\
\end{array}$ & $\begin{array}{c}1,653 \\
0.0801 \\
F(34,1618) \\
=2.28^{* * *} \\
\end{array}$ & $\begin{array}{c}1,653 \\
0.0528 \\
F(31,1621) \\
=2.60^{* * *} \\
\end{array}$ & $\begin{array}{c}1,621 \\
0.1008 \\
F(31,1589) \\
=2.80^{* * *}\end{array}$ & $\begin{array}{c}1,621 \\
0.1026 \\
F(34,1586) \\
=2.56^{* * *}\end{array}$ & $\begin{array}{c}1,621 \\
0.0370 \\
F(31,1589)= \\
2.36^{* * *}=\end{array}$ \\
\hline $\begin{array}{l}\text { Exclusion restr. tests: } \\
\text { T1: saving=risky } \\
\text { assets }=0 \\
\text { T2: } \text { medium=large } \\
\text { =big city=0 } \\
\text { T3: T1\&T2 }\end{array}$ & $\begin{array}{l}F(2,1628)= \\
0.53 \\
F(3,1628)= \\
1.50 \\
F(5,1628)= \\
1.16\end{array}$ & & $\begin{array}{l}F(2,1628)= \\
3.38^{*} \\
F(3,1628)= \\
4.82^{*} \\
F(5,628)= \\
4.36^{* * *}\end{array}$ & $\begin{array}{l}F(2,1621)= \\
0.47 \\
F(3,1621)= \\
0.74 \\
F(5,1621)= \\
0.62\end{array}$ & & $\begin{array}{l}F(2,1621)= \\
2.18 \\
F(3,1621)= \\
5.15^{*} \\
F(5,1621)= \\
3.66^{*}\end{array}$ & $\begin{array}{l}F(2,1589)= \\
1.02 \\
F(3,1589)= \\
3.29^{*} \\
F(5,1589)= \\
2.33^{*}\end{array}$ & & $\begin{array}{l}F(2,1589)= \\
1.04 \\
F(3,1589)= \\
1.13 \\
F(5,1589)= \\
1.10\end{array}$ \\
\hline
\end{tabular}

${ }^{1}$ See Table 14. ${ }^{+} \mathrm{p}<0.10,{ }^{*} \mathrm{p}<0.05, * * \mathrm{p}<0.01, * * * \mathrm{p}<0.001$. 
Table 17. Subscription rates to FPAs. Cross section LPM estimates (samples out of balanced panel) ${ }^{1}$

\begin{tabular}{|c|c|c|c|}
\hline & 2010 & 2012 & 2014 \\
\hline equivalent income deciles & & & \\
\hline 2nd & $\begin{array}{l}-0.0133 \\
(-0.75)\end{array}$ & $\begin{array}{c}-0.00641 \\
(-0.77)\end{array}$ & $\begin{array}{c}-0.00780+ \\
(-1.86)\end{array}$ \\
\hline $3 \mathrm{rd}$ & $\begin{array}{r}-0.0204 \\
(-1.27)\end{array}$ & $\begin{array}{c}-0.0190 * * \\
(-2.96)\end{array}$ & $\begin{array}{c}0.00121 \\
(0.12)\end{array}$ \\
\hline 4th & $\begin{array}{l}-0.0162 \\
(-0.92)\end{array}$ & $\begin{array}{c}-0.00103 \\
(-0.09)\end{array}$ & $\begin{array}{c}-0.00518 \\
(-0.53)\end{array}$ \\
\hline 5 th & $\begin{array}{r}-0.0177 \\
(-1.01)\end{array}$ & $\begin{array}{l}0.0118 \\
(0.82)\end{array}$ & $\begin{array}{c}0.00426 \\
(0.35)\end{array}$ \\
\hline 6th & $\begin{array}{c}0.00767 \\
(0.37)\end{array}$ & $\begin{array}{l}-0.0161 \\
(-1.31)\end{array}$ & $\begin{array}{c}0.0297+ \\
(1.75)\end{array}$ \\
\hline 7th & $\begin{array}{l}0.0199 \\
(0.90)\end{array}$ & $\begin{array}{c}-0.00573 \\
(-0.39)\end{array}$ & $\begin{array}{l}0.0154 \\
(1.07)\end{array}$ \\
\hline 8th & $\begin{array}{l}-0.0213 \\
(-1.20)\end{array}$ & $\begin{array}{c}0.00307 \\
(0.18)\end{array}$ & $\begin{array}{l}0.0260 \\
(1.51)\end{array}$ \\
\hline 9th & $\begin{array}{c}0.00467 \\
(0.22)\end{array}$ & $\begin{array}{l}-0.00353 \\
(-0.22)\end{array}$ & $\begin{array}{l}0.0154 \\
(0.97)\end{array}$ \\
\hline 10th & $\begin{array}{l}0.0224 \\
(1.01)\end{array}$ & $\begin{array}{c}0.0307+ \\
(1.71)\end{array}$ & $\begin{array}{c}0.0151 \\
(0.91)\end{array}$ \\
\hline $\begin{array}{l}\text { demographic characteristics } \\
\text { age }\end{array}$ & $\begin{array}{c}0.00297 \\
(0.76)\end{array}$ & $\begin{array}{c}0.00296 \\
(0.68)\end{array}$ & $\begin{array}{c}0.00816^{*} \\
(2.48)\end{array}$ \\
\hline age squared & $\begin{array}{c}-0.0000216 \\
(-0.48)\end{array}$ & $\begin{array}{c}-0.0000268 \\
(-0.57)\end{array}$ & $\begin{array}{c}-0.0000756^{*} \\
(-2.13)\end{array}$ \\
\hline female & $\begin{array}{c}-0.0203^{* *} \\
(-2.71)\end{array}$ & $\begin{array}{c}-0.0166^{*} \\
(-2.05)\end{array}$ & $\begin{array}{c}-0.0185^{*} \\
(-2.01)\end{array}$ \\
\hline upper secondary & $\begin{array}{l}0.0138+ \\
(1.79)\end{array}$ & $\begin{array}{l}0.0107 \\
(1.22)\end{array}$ & $\begin{array}{l}0.0129 \\
(1.42)\end{array}$ \\
\hline university degree & $\begin{array}{l}0.0174 \\
(1.49)\end{array}$ & $\begin{array}{c}0.0382^{*} \\
(2.52)\end{array}$ & $\begin{array}{l}0.0227 \\
(1.50)\end{array}$ \\
\hline single & $\begin{array}{c}0.00180 \\
(0.13)\end{array}$ & $\begin{array}{c}0.00471 \\
(0.28)\end{array}$ & $\begin{array}{l}-0.0131 \\
(-1.09)\end{array}$ \\
\hline widow(er) & $\begin{array}{l}0.0208 \\
(1.20)\end{array}$ & $\begin{array}{l}-0.00395 \\
(-0.33)\end{array}$ & $\begin{array}{c}0.00511 \\
(0.33)\end{array}$ \\
\hline private employee & $\begin{array}{c}0.0159^{*} \\
(2.57)\end{array}$ & $\begin{array}{c}0.00743 \\
(0.98)\end{array}$ & $\begin{array}{c}0.00612 \\
(0.44)\end{array}$ \\
\hline public employee & $\begin{array}{c}0.00276 \\
(0.36)\end{array}$ & $\begin{array}{c}0.00760 \\
(0.67)\end{array}$ & $\begin{array}{c}-0.00990 \\
(-0.78)\end{array}$ \\
\hline small firm (5- 49 workers) & $\begin{array}{l}0.0167^{*} \\
(2.03)\end{array}$ & $\begin{array}{c}0.0214^{* *} \\
(2.65)\end{array}$ & $\begin{array}{l}-0.0131 \\
(-1.13)\end{array}$ \\
\hline medium firm (50-99 workers) & $\begin{array}{l}0.00146 \\
(0.11)\end{array}$ & $\begin{array}{l}0.0413 \\
(1.49)\end{array}$ & $\begin{array}{l}0.0339 \\
(1.29)\end{array}$ \\
\hline big firm (100+ workers) & $\begin{array}{c}0.0528^{* * *} \\
(3.50)\end{array}$ & $\begin{array}{c}0.0334^{*} \\
(2.48)\end{array}$ & $\begin{array}{c}0.0300+ \\
(1.69)\end{array}$ \\
\hline Resident in the North & $\begin{array}{c}0.00184 \\
(0.23)\end{array}$ & $\begin{array}{l}0.0120 \\
(1.14)\end{array}$ & $\begin{array}{c}0.00564 \\
(0.50)\end{array}$ \\
\hline Resident in the Centre & $\begin{array}{l}-0.00843 \\
(-0.88)\end{array}$ & $\begin{array}{c}-0.00214 \\
(-0.18)\end{array}$ & $\begin{array}{c}-0.0222^{*} \\
(-2.01)\end{array}$ \\
\hline $\begin{array}{l}\text { housing wealth } \\
\text { home owner }\end{array}$ & $\begin{array}{c}-0.00273 \\
(-0.32)\end{array}$ & $\begin{array}{l}0.0179 * \\
(2.13)\end{array}$ & $\begin{array}{c}0.00887 \\
(1.04)\end{array}$ \\
\hline mortgagee & $\begin{array}{l}0.0184 \\
(1.48)\end{array}$ & $\begin{array}{c}-0.000636 \\
(-0.05)\end{array}$ & $\begin{array}{l}0.0188 \\
(1.24)\end{array}$ \\
\hline $\begin{array}{l}\text { financial strength } \\
\text { positive saving }\end{array}$ & $\begin{array}{l}-0.00576 \\
(-0.73)\end{array}$ & $\begin{array}{c}0.00897 \\
(0.90)\end{array}$ & $\begin{array}{l}0.0124 \\
(1.08)\end{array}$ \\
\hline $\begin{array}{l}\text { risky asset owner } \\
\text { sellers' local availability }\end{array}$ & $\begin{array}{l}0.0201 \\
(1.43)\end{array}$ & $\begin{array}{l}0.0105 \\
(0.63)\end{array}$ & $\begin{array}{c}0.00163 \\
(0.10)\end{array}$ \\
\hline medium city $(20,000$ to 40,000$)$ & $\begin{array}{c}0.00180 \\
(0.16)\end{array}$ & $\begin{array}{c}0.00443 \\
(0.34)\end{array}$ & $\begin{array}{l}0.0139 \\
(1.03)\end{array}$ \\
\hline large city $(40,000$ to 500,000$)$ & $\begin{array}{c}-0.00416 \\
(-0.47)\end{array}$ & $\begin{array}{l}-0.00773 \\
(-0.76)\end{array}$ & $\begin{array}{c}0.00302 \\
(0.30)\end{array}$ \\
\hline big city $(500,000+)$ & $\begin{array}{c}-0.0338^{* * *} \\
(-3.63)\end{array}$ & $\begin{array}{r}-0.0110 \\
(-0.63)\end{array}$ & $\begin{array}{c}-0.00802 \\
(-0.51)\end{array}$ \\
\hline $\begin{array}{l}\text { finlit_3 } \\
\text { constant }\end{array}$ & $\begin{array}{c}0.00369 \\
(0.49) \\
-0.0886 \\
(-1.07)\end{array}$ & $\begin{array}{c}-0.00680 \\
(-0.78) \\
-0.0904 \\
(-0.89)\end{array}$ & $\begin{array}{c}-0.00471 \\
(-0.54) \\
-0.217^{* *} \\
(-2.84)\end{array}$ \\
\hline $\begin{array}{l}\text { Number of obs } \\
\text { R-squared }\end{array}$ & $\begin{array}{c}1,660 \\
0.0540 \\
F(31,1628)=1.23\end{array}$ & $\begin{array}{c}1,653 \\
0.0370 \\
F(31,1621)=1.55^{*}\end{array}$ & $\begin{array}{c}1,621 \\
0.0376 \\
F(31,1589)=1.52^{*}\end{array}$ \\
\hline $\begin{array}{l}\text { Exclusion restrictions tests: } \\
\text { T1: saving=risky assets }=0\end{array}$ & $F(2,1628)=1.32$ & $F(2,1621)=0.67$ & $F(2,1589)=0.73$ \\
\hline T2: medium=large $=$ big city $=0$ & $F(3,1628)=6.42^{* * *}$ & $F(3,1621)=0.51$ & $F(3,1589)=0.64$ \\
\hline T3: T1\&T2 & $F(5,1628)=4.39 * * *$ & $F(5,1621)=0.55$ & $F(5,1589)=0.63$ \\
\hline
\end{tabular}

${ }^{1}$ See Table 14. ${ }^{+} \mathrm{p}<0.10,{ }^{*} \mathrm{p}<0.05,{ }^{*} \mathrm{p}<<0.01, * * * \mathrm{p}<0.001$. 
Table 18. Average marginal effects for cross sections out of balanced panel (probit estimates at age $=45$; baseline specifications with finlit_3 indicator interacted with city size; only statistically significant effects ${ }^{1}$

\begin{tabular}{|c|c|c|c|c|c|c|c|}
\hline & female & $\begin{array}{l}\text { positive } \\
\text { saving }\end{array}$ & $\begin{array}{l}\text { risky } \\
\text { asset } \\
\text { holder }\end{array}$ & $\begin{array}{l}\text { medium } \\
\text { city }(20,000 \\
\text { to } 40,000)\end{array}$ & $\begin{array}{l}\text { large city } \\
(40,000 \text { to } \\
500,000)\end{array}$ & $\begin{array}{l}\text { big city } \\
(500,000 \\
+)\end{array}$ & $\begin{array}{l}\text { finlit_3 with } \\
\text { interactions }\end{array}$ \\
\hline & \multicolumn{6}{|c|}{$2010($ Obs = 1660) } & \\
\hline PENS & $-0.08 * * *$ & & & $-0.12 * * *$ & $-0.08 * * *$ & $-0.10 *$ & \\
\hline PIPs & $-0.05 * * *$ & $0.03^{+}$ & & $-0.09 * * *$ & $-0.07 * * *$ & & \\
\hline - PIPCs & $-0.02^{+}$ & & & $-0.02^{+}$ & & & $-0.02^{+}$ \\
\hline - PIPNCs & $-0.04 * * *$ & $0.03 * *$ & & $-0.06 * * *$ & $-0.05 * *$ & & \\
\hline \multirow[t]{2}{*}{$\begin{array}{l}\text { FPAs } \\
(1445)\end{array}$} & $-0.02 * *$ & & & & & & \\
\hline & \multicolumn{6}{|c|}{$2012($ Obs = 1653) } & \\
\hline PENS & $-0.07 * *$ & & $0.06+$ & $-0.10 * *$ & $-0.06^{*}$ & $-0.07+$ & \\
\hline PIPs & $-0.05 * *$ & & & $-0.08^{* * * *}$ & $-0.06 * *$ & $-0.09 * *$ & \\
\hline - PIPCs & $-0.03 *$ & & & & & $-0.03^{+}$ & $-0.02^{+}$ \\
\hline - PIPNCS & $-0.3^{*}$ & $0.03 *$ & & $-0.07 * * *$ & $-0.06 * * *$ & $-0.06^{*}$ & \\
\hline \multirow[t]{2}{*}{$\begin{array}{l}\text { FPAs } \\
(1518)\end{array}$} & $-0.02 *$ & & & & & & \\
\hline & \multicolumn{6}{|c|}{$2014($ Obs $=1621)$} & \\
\hline PENS & $-0.08 * * *$ & & & $-0.06^{+}$ & $-0.08 * *$ & $-0.12 * *$ & \\
\hline PIPs & $-0.03^{+}$ & & & $-0.06^{*}$ & $-0.09 * * *$ & $-0.09 * *$ & $-0.03^{+}$ \\
\hline - PIPCs & $-0.03 * *$ & & & $-0.03^{+}$ & $-0.05 * *$ & $-0.06 * *$ & $-0.04 * * *$ \\
\hline - PIPNCS & & & & & $-0.03^{+}$ & & \\
\hline $\begin{array}{l}\text { FPAs } \\
(1513)\end{array}$ & $-0.02 *$ & & & & & & \\
\hline
\end{tabular}

${ }^{1}$ See Tables 14 and A.3, and Appendix for wording. Within brackets in the first column no of observations used for FPAs probit estimates. ${ }^{+} \mathrm{p}<0.10, * \mathrm{p}<0.05, * * \mathrm{p}<0.01, * * * \mathrm{p}<0.001$.

Table 19. Average marginal (differential) effects of alternative financial literacy indicators interacted with city size. Only statistically significant estimates in cross sections out of balanced panel (probit estimates at age $=45$ ); wave in brackets ${ }^{1}$

\begin{tabular}{|c|c|c|c|c|c|c|c|c|}
\hline & $\begin{array}{l}\text { Mortgage } \\
\text { (1) }\end{array}$ & $\begin{array}{l}\text { Interest rate } \\
\text { and inflation } \\
\text { (2) }\end{array}$ & $\begin{array}{c}\text { Risk } \\
\text { diversification } \\
\text { (3) }\end{array}$ & (1) \& (3) & (2) \& (3) & (1) \& (2) & At least two & $\begin{array}{c}\text { (1) \& (2) \& (3) } \\
\text { finlit_3 }\end{array}$ \\
\hline PIPs & & & & $-0.03^{+}(2014)$ & & & & $-0.03^{+}(2014)$ \\
\hline - PIPCS & $\begin{array}{l}-0.03 * *(2010) \\
-0.03 *(2014)\end{array}$ & - & $-0.03^{* *}(2014)$ & $\begin{array}{c}-0.02^{+}(2012) \\
-0.04 * * *(2014)\end{array}$ & $\begin{array}{l}-0.02 * *(2010) \\
-0.03^{* *}(2014)\end{array}$ & $\begin{array}{l}-0.02^{+}(2010) \\
-0.03^{*}(2014)\end{array}$ & - & $\begin{array}{c}-0.02^{+}(2010) \\
-0.022^{2}(2012) \\
-0.04 * * *(2014)\end{array}$ \\
\hline - PIPNCs & $0.02^{+}(2012)$ & $0.03^{* * *}(2014)$ & & & & $\begin{array}{l}0.02^{+}(2012) \\
0.03^{+}(2014)\end{array}$ & $0.02^{+}(2012)$ & \\
\hline FPAs & & $-0.04 *(2010)$ & $\begin{array}{c}\mathbf{O . 0 1}^{+}(\mathbf{2 0 1 0}) \\
-0.02^{+}(2012)\end{array}$ & & $-0.03^{* * *}(2012)$ & & $-0.03^{+}(2012)$ & \\
\hline
\end{tabular}

${ }^{1}$ See Tables 14 and A.3, and Appendix for wording. LPM estimates (with no interactions) in bold italics when the probit estimates are not significant or not available for lack of convergence. ${ }^{+} \mathrm{p}<0.10,{ }^{*} \mathrm{p}<0.05, * * \mathrm{p}<0.01, * * * \mathrm{p}<0.001$. 
Appendix. Tables

Table A.1

Pension funds and sub-funds by investment - Net annual return rates (percentages)

\begin{tabular}{lcccccccccc} 
& $\mathbf{2 0 0 8}$ & $\mathbf{2 0 0 9}$ & $\mathbf{2 0 1 0}$ & $\mathbf{2 0 1 1}$ & $\mathbf{2 0 1 2}$ & $\mathbf{2 0 1 3}$ & $\mathbf{2 0 1 4}$ & $\mathbf{2 0 1 5}$ & $\mathbf{2 0 1 6}$ & $\mathbf{2 0 1 7}$ \\
\hline Occupational Funds (FPNs) & $\mathbf{- 6 . 3}$ & $\mathbf{8 . 5}$ & $\mathbf{3 . 0}$ & $\mathbf{0 . 1}$ & $\mathbf{8 . 2}$ & $\mathbf{5 . 4}$ & $\mathbf{7 . 3}$ & $\mathbf{2 . 7}$ & $\mathbf{2 . 7}$ & $\mathbf{2 . 6}$ \\
Guaranteed & 3.1 & 4.6 & 0.2 & -0.5 & 7.7 & 3.1 & 4.6 & 1.9 & 0.8 & 0.8 \\
Bonds & 1.6 & 2.9 & 0.4 & 1.7 & 3.0 & 1.2 & 1.2 & 0.5 & 0.2 & -0.2 \\
Mixed bonds & -3.9 & 8.1 & 3.6 & 1.1 & 8.1 & 5.0 & 8.1 & 2.7 & 3.2 & 2.6 \\
Balanced & -9.4 & 10.4 & 3.6 & -0.6 & 9.2 & 6.6 & 8.5 & 3.2 & 3.2 & 3.1 \\
All shares & -24.5 & 16.1 & 6.2 & -3.0 & 11.4 & 12.8 & 9.8 & 5.0 & 4.4 & 5.9 \\
\hline Open Funds (FPAs) & $\mathbf{- 1 4 . 0}$ & $\mathbf{1 1 . 3}$ & $\mathbf{4 . 2}$ & $\mathbf{- 2 . 4}$ & $\mathbf{9 . 1}$ & $\mathbf{8 . 1}$ & $\mathbf{7 . 5}$ & $\mathbf{3 . 0}$ & $\mathbf{2 . 2}$ & $\mathbf{3 . 3}$ \\
Guaranteed & 1.9 & 4.8 & 0.7 & -0.3 & 6.6 & 2.0 & 4.3 & 0.9 & 0.7 & 0.6 \\
Bonds & 4.9 & 4.0 & 1.0 & 1.0 & 6.4 & 0.8 & 6.9 & 0.9 & 1.3 & -0.3 \\
Mixed bonds & -2.2 & 6.7 & 2.6 & 0.4 & 8.0 & 3.6 & 8.0 & 2.2 & 1.4 & 0.4 \\
Balanced & -14.2 & 12.6 & 4.7 & -2.3 & 10.0 & 8.3 & 8.7 & 3.7 & 2.7 & 3.7 \\
All shares & -27.6 & 17.7 & 7.2 & -5.3 & 10.8 & 16.0 & 8.7 & 4.2 & 3.2 & 7.2 \\
\hline "New" PIPs & & & & & & & & & & \\
Traditional Life Policies (Ramo I) & $\mathbf{3 . 1}$ & $\mathbf{3 . 1}$ & $\mathbf{3 . 2}$ & $\mathbf{3 . 2}$ & $\mathbf{3 . 3}$ & $\mathbf{3 . 2}$ & $\mathbf{2 . 9}$ & $\mathbf{2 . 5}$ & $\mathbf{2 . 1}$ & $\mathbf{1 . 9}$ \\
Unit linked (Ramo III) & $\mathbf{- 2 1 . 9}$ & $\mathbf{1 4 . 5}$ & $\mathbf{4 . 7}$ & $\mathbf{- 5 . 2}$ & $\mathbf{7 . 9}$ & $\mathbf{1 0 . 9}$ & $\mathbf{6 . 8}$ & $\mathbf{3 . 2}$ & $\mathbf{3 . 6}$ & $\mathbf{2 . 2}$ \\
$\quad$ Bonds & 2.4 & 3.7 & 0.6 & 0.8 & 4.9 & -0.3 & 3.3 & 0.6 & 0.4 & -0.7 \\
Balanced & -8.3 & 7.8 & 2.5 & -3.5 & 6.4 & 5.8 & 8.2 & 1.9 & 1.5 & 2.3 \\
All shares & -32.4 & 20.6 & 6.7 & -7.9 & 9.6 & 17.2 & 7.1 & 4.5 & 6.0 & 3.2 \\
\hline Memorandum items: & & & & & & & & & & $\mathbf{1 . 7}$ \\
TFR revaluation rate & $\mathbf{2 . 7}$ & $\mathbf{2 . 0}$ & $\mathbf{2 . 6}$ & $\mathbf{3 . 5}$ & $\mathbf{2 . 9}$ & $\mathbf{1 . 7}$ & $\mathbf{1 . 3}$ & $\mathbf{1 . 2}$ & $\mathbf{1 . 5}$ &
\end{tabular}

Source: COVIP (2018). Return rates are net of management fees and of the substitute tax.

Table A.2 Descriptive statistics (averages): employed household heads estimation full sample (\% of observations, except for age)

\begin{tabular}{|c|c|c|c|}
\hline & 2010 obs $=5,347$ & 2012 obs $=5,158$ & 2014 obs $=4,810$ \\
\hline PENS & 0.2040396 & 0.1927104 & 0.1848233 \\
\hline PIPs & 0.0978119 & 0.0878247 & 0.0858628 \\
\hline PIPCs & 0.0426407 & 0.0453664 & 0.0467775 \\
\hline $\begin{array}{ll}- & \text { PIPNCs } \\
\end{array}$ & 0.0551711 & 0.0424583 & 0.0390852 \\
\hline FPAs & 0.0246867 & 0.0224893 & 0.0237006 \\
\hline \multicolumn{4}{|c|}{ Explanatory variables } \\
\hline \multicolumn{4}{|l|}{ equivalent income deciles } \\
\hline 2nd & 0.0684496 & 0.0779372 & 0.0715177 \\
\hline $3 \mathrm{rd}$ & 0.0710679 & 0.084335 & 0.0814969 \\
\hline 4th & 0.090144 & 0.0911206 & 0.0891892 \\
\hline 5 th & 0.0965027 & 0.1013959 & 0.1079002 \\
\hline 6th & 0.1095942 & 0.1157425 & 0.1079002 \\
\hline 7th & 0.1217505 & 0.1147732 & 0.1201663 \\
\hline 8th & 0.1344679 & 0.1213649 & 0.12079 \\
\hline 9th & 0.1322237 & 0.1221404 & 0.131185 \\
\hline 10th & 0.135216 & 0.1219465 & 0.129106 \\
\hline \multicolumn{4}{|l|}{ demographic characteristics } \\
\hline age & 46.55152 & 47.31873 & 48.58462 \\
\hline female & 0.4346362 & 0.4290423 & 0.4405405 \\
\hline upper secondary & 0.4572658 & 0.4567662 & 0.460499 \\
\hline university degree & 0.1829063 & 0.191547 & 0.2 \\
\hline single & 0.117823 & 0.1203955 & 0.1405405 \\
\hline widow(er) & 0.0922012 & 0.0946103 & 0.1068607 \\
\hline private employee & 0.5447915 & 0.565917 & 0.6130977 \\
\hline public employee & 0.2545353 & 0.2382706 & 0.1925156 \\
\hline small firm (5- 49) & 0.2605199 & 0.2557193 & 0.2650728 \\
\hline medium firm (50-99) & 0.0475033 & 0.0407135 & 0.0575884 \\
\hline big firm $(100+)$ & 0.1421358 & 0.1475378 & 0.1746362 \\
\hline resident in the North & 0.4729755 & 0.4682047 & 0.5072765 \\
\hline resident in the Centre & 0.2208715 & 0.2200465 & 0.2066528 \\
\hline $\begin{array}{l}\text { housing wealth } \\
\text { home owner }\end{array}$ & 0.6861792 & 0.7022102 & 0.712266 \\
\hline mortgagee & 0.1673836 & 0.1903839 & 0.1754678 \\
\hline \multicolumn{4}{|l|}{ financial strength } \\
\hline saving $>0$ & 0.4043389 & 0.283637 & 0.3012474 \\
\hline risky asset owner & 0.1406396 & 0.1101202 & 0.122869 \\
\hline $\begin{array}{l}\text { sellers' local availability } \\
\text { medium city }(20,000 \text { to } 40,000)\end{array}$ & 0.1864597 & 0.1882513 & 0.1972973 \\
\hline large city $(40,000$ to 500,000$)$ & 0.4580138 & 0.475378 & 0.45634 \\
\hline big city $(500,000+)$ & 0.0979989 & 0.084335 & 0.0808732 \\
\hline
\end{tabular}

Source: own computation from SHIW. 
Table A.3 Descriptive statistics (averages): employed household heads estimation BP sample (\% of observations except for age)

\begin{tabular}{|c|c|c|c|}
\hline & $2010($ obs $=1660)$ & $2012($ obs $=1653)$ & $2014($ obs = 1621) \\
\hline PENS & 0.2174699 & 0.2171809 & 0.2220851 \\
\hline PIPs & 0.1072289 & 0.102843 & 0.102406 \\
\hline PIPCs & 0.0493976 & 0.047792 & 0.053671 \\
\hline - $\quad$ PIPNCs & 0.0578313 & 0.055051 & 0.048735 \\
\hline FPAs & 0.0222892 & 0.029038 & 0.029611 \\
\hline \multicolumn{4}{|c|}{ Financial literacy level indicators: correct answers to 2010 SHIW three questions } \\
\hline Three & 0.4481928 & 0.4440411 & 0.4361505 \\
\hline At least two & 0.7716867 & 0.7701149 & 0.770512 \\
\hline $\begin{array}{l}\text { Risk diversification \& interest rate and } \\
\text { inflation }\end{array}$ & 0.5903614 & 0.5898367 & 0.5848242 \\
\hline Risk diversification \& mortgage & 0.4783133 & 0.4742892 & 0.4663788 \\
\hline Mortgage \& interest rate and inflation & 0.6198795 & 0.61464 & 0.6125848 \\
\hline Risk diversification & 0.6445783 & 0.6448881 & 0.6403455 \\
\hline Interest rate and inflation & 0.8319277 & 0.8294011 & 0.8297347 \\
\hline Mortgage & 0.696988 & 0.6908651 & 0.6890808 \\
\hline \multicolumn{4}{|c|}{ Explanatory variables } \\
\hline \multicolumn{4}{|l|}{ equivalent income deciles } \\
\hline 2nd & 0.0771084 & 0.0786449 & 0.0666255 \\
\hline $3 \mathrm{rd}$ & 0.0680723 & 0.0816697 & 0.089451 \\
\hline 4th & 0.0939759 & 0.0931639 & 0.0808143 \\
\hline 5th & 0.1072289 & 0.0949788 & 0.1098088 \\
\hline 6th & 0.1120482 & 0.1028433 & 0.1030228 \\
\hline 7th & 0.1186747 & 0.1058681 & 0.114744 \\
\hline 8th & 0.1283133 & 0.1246219 & 0.1135102 \\
\hline 9th & 0.1289157 & 0.1361162 & 0.1264651 \\
\hline $\begin{array}{l}\text { 10th } \\
\text { demographic characteristics }\end{array}$ & 0.1277108 & 0.1409558 & 0.1505244 \\
\hline age & 46.45361 & 48.38113 & 50.2992 \\
\hline female & 0.4343373 & 0.4361766 & 0.4380012 \\
\hline upper secondary & 0.4686747 & 0.4700544 & 0.4682295 \\
\hline university degree & 0.1801205 & 0.1869328 & 0.1893893 \\
\hline single & 0.0855422 & 0.0865094 & 0.0851326 \\
\hline widow(er) & 0.0704819 & 0.0816697 & 0.0869833 \\
\hline private employee & 0.5427711 & 0.5517241 & 0.5959284 \\
\hline public employee & 0.2674699 & 0.2625529 & 0.2140654 \\
\hline small firm $(5-49)$ & 0.253012 & 0.2450091 & 0.2646514 \\
\hline medium firm (50-99) & 0.0638554 & 0.0429522 & 0.057372 \\
\hline big firm $(100+)$ & 0.1409639 & 0.1578947 & 0.1739667 \\
\hline Resident in the North & 0.4481928 & 0.4506957 & 0.446021 \\
\hline Resident in the Centre & 0.203012 & 0.200242 & 0.2048118 \\
\hline \multicolumn{4}{|l|}{ housing wealth } \\
\hline home owner & 0.7337349 & 0.7477314 & 0.7532387 \\
\hline mortgagee & 0.1759036 & 0.1857229 & 0.1616286 \\
\hline \multicolumn{4}{|l|}{ financial strength } \\
\hline saving $>0$ & 0.4204819 & 0.322444 & 0.3103023 \\
\hline risky asset owner & 0.1674699 & 0.1300665 & 0.1468229 \\
\hline $\begin{array}{l}\text { sellers' local availability } \\
\text { medium city ( }(20,000 \text { to } 40,000)\end{array}$ & 0.1927711 & 0.1972172 & 0.2029611 \\
\hline large city $(40,000$ to 500,000$)$ & 0.4566265 & 0.4519056 & 0.4528069 \\
\hline big city $(500,000+)$ & 0.0656627 & 0.0653358 & 0.0623072 \\
\hline
\end{tabular}

Source: own computation from SHIW. 
71 Spending Policies of Italian Banking Foundations, by Pattarin, F. (July, 2018).

70 The Forecasting Performance of Dynamic Factors Models with Vintage Data, by Di Bonaventura, L., Forni, M. and Pattarin, F. (July 2018).

69 Housing Market Shocks in Italy: a GVAR Approach, by Cipollini, A. and Parla, F. (April, 2018).

68 Customer Complaining and Probability of Default in Consumer Credit, by Cosma, S., Pancotto, F. and Vezzani, P. (March, 2018).

67 Is Equity Crowdfunding a Good Tool for Social Enterprises?, by Cosma, S., Grasso, A.G., Pagliacci, F. and Pedrazzoli, A. (February, 2018).

66 Household Preferences for Socially Responsible Investments, by Rossi. M.C., Sansone, D., Torricelli, C. and van Soest, A. (February2018).

65 Market-Book Ratios of European Banks: What does Explain the Structural Fall?, by Ferretti, R.,Gallo, G., Landi, A. and Venturelli. V. (January 2018).

64 Past Income Scarcity and Current Perception of Financial Fragility, by Baldini, M., Gallo, G. and Torricelli, C. (December 2017).

63 How does Financial Market Evaluate Business Models? Evidence from European Banks, by Cosma, S., Ferretti, R.,Gualandri, E., Landi, A. and Venturelli, V. (May 2017) Individual Heterogeneity and Pension Choices. How to Communicate an Effective Message?, by Gallo, G., Torricelli, C. and van Soest, A. (April 2017)

61 The Risk-Asymmetry Index, by Elyasiani, E., Gambarelli L. and Muzzioli, S.(December 2016)

60 Strumenti per il sostegno finanziario di famiglie e microimprese: il caso italiano (Policies to help financially vulnerable Italian households and micro-businesses),

by Cotterli, S. (December 2016)

59 A test of the Behavioral versus the Rational model of Persuasion in Financial Advertising, by Ferretti, R., Pancotto, F. and Rubaltelli, E. (May 2016)

58 Financial connectedness among European volatility risk premia, by Cipollini, A., Lo Cascio, I. and Muzzioli, S. (December 2015)

57 The effectiveness of insider trading regulations. The case of the Italian tender offers, by Ferretti, R., Pattitoni, P. and Salinas, A. (September 2015)

56 Introducing Aggregate Return on Investment as a Solution for the Contradiction between some PME Metrics and IRR, by Altshuler D. and Magni, C.A. (September 2015)

55 'It's a trap!' The degree of poverty persistence in Italy and Europe, by Giarda, E. and Moroni, G. (September 2015)

54 Systemic risk measures and macroprudential stress tests. An assessment over the 2014 EBA exercise. by Pederzoli, C. and Torricelli,C. (July 2015)

53 Emotional intelligence and risk taking in investment decision-making, by Rubaltelli, E., 
Agnoli, S., Rancan, M.and Pozzoli, T. (July 2015)

52 Second homes: households' life dream or wrong investment?, by Brunetti, M. and Torricelli, C. (May 2015)

51 Pseudo-naïve approaches to investment performance measurement, by Magni, C.A. (February, 2015)

50 Monitoring systemic risk. A survey of the available macroprudential Toolkit, by Gualandri, E. and Noera, M. (November 2014).

49 Towards a macroprudential policy in the EU: Main issues, by Gualandri, E. and Noera, M. (November 2014).

48 Does homeownership partly explain low participation in supplementary pension schemes?, by Santantonio, M., Torricelli, C., and Urzì Brancati M.C., (September 2014)

47 An average-based accounting approach to capital asset investments: The case of project finance, by Magni, C.A. (September 2014)

46 Should football coaches wear a suit? The impact of skill and management structure on Serie $A$ Clubs' performance, by Torricelli, C., Urzì Brancati M.C., and Mirtoleni, L. (July 2014)

45 Family ties: occupational responses to cope with a household income shock, by Baldini, M., Torricelli, C., Urzì Brancati M.C. (April 2014)

44 Volatility co-movements: a time scale decomposition analysis, by Cipollini, I., Lo Cascio I., Muzzioli. S. (November 2013)

43 The effect of revenue and geographic diversification on bank performance, by Brighi, P., Venturelli, V. (October 2013)

42 The sovereign debt crisis: the impact on the intermediation model of Italian banks, by Cosma,S., Gualandri, E. (October 2013)

41 The financing of Italian firms and the credit crunch: findings and exit strategies, by Gualandri, E., Venturelli, V. (October 2013)

40 Efficiency and unbiasedness of corn futures markets: New evidence across the financial crisis, by Pederzoli, C., Torricelli, C. (October 2013)

39 La regolamentazione dello short selling: effetti sul mercato azionario italiano (Short selling ban: effects on the Italian stock market), by Mattioli L., Ferretti R. (August 2013)

38 A liquidity risk index as a regulatory tool for systematically important banks? An empirical assessment across two financial crises, by Gianfelice G., Marotta G., Torricelli C. (July 2013)

37 Per un accesso sostenibile delle Pmi al credito (A sustainable access to credit for SMEs), by Marotta, G. (May 2013)

36 The unavoidable persistence of forum shopping in the Insolvency Regulation, by Mucciarelli, F.M. (April 2013)

35 Rating Triggers, Market Risk and the Need for More Regulation, by Parmeggiani, F. (December 2012)

CEFIN - Centro Studi di Banca e Finanza www.cefin.unimore.it Dipartimento di Economia Marco Biagi - Università di Modena e Reggio Emilia Viale Jacopo Berengario 51, 41121 MODENA (Italy) tel. 39-059.2056711 (Centralino) fax 39-059 2056927 


\section{UNIMORE CEFIN}

\section{UNIVERSITÀ DEGLI STUDI DI MODENA E REGGIO EMILIA \\ Centro Studi Banca e Finanza}

34 Collateral Requirements of SMEs: The Evidence from Less-Developed Countries,

by Hanedar, E.H. Broccardo, E. and Bazzana, F. (November 2012)

33 Is it money or brains? The determinants of intra-family decision power, by Bertocchi, G., Brunetti, M. and Torricelli, C. (June 2012)

32 Is financial fragility a matter of illiquidity? An appraisal for Italian households, by Brunetti, M, Giarda, E. and Torricelli, C. (June 2012)

31 Attitudes, personality factors and household debt decisions: A study of consumer credit, by Stefano Cosma and Francesco Pattarin (February 2012)

30 Corridor implied volatility and the variance risk premium in the Italian market, by Silvia Muzzioli (November 2011)

29 Internal Corporate Governance and the Financial Crisis: Lessons for Banks, Regulators and Supervisors, by Gualandri, E., Stanziale, A. and Mangone, E. (November 2011)

28 Are defined contribution pension schemes socially sustainable? A conceptual map from a macroprudential perspective, by Marotta, G. (October 2011)

27 Basel 3, Pillar 2: the role of banks' internal governance and control function, by Gualandri, E. (September 2011)

26 Underpricing, wealth loss for pre-existing shareholders and the cost of going public: the role of private equity backing in Italian IPOs, by Ferretti, R. and Meles, A. (April 2011)

25 Modelling credit risk for innovative firms: the role of innovation measures, by Pederzoli C., Thoma G., Torricelli C. (March 2011)

24 Market Reaction to Second-Hand News: Attention Grabbing or Information Dissemination?, by Cervellati E.M., Ferretti R., Pattitoni P. (January 2011)

23 Towards a volatility index for the Italian stock market, by Muzzioli S. (September 2010)

22 A parsimonious default prediction model for Italian SMEs, by Pederzoli C., Torricelli C. (June 2010)

21 Average Internal Rate of Return and investment decisions: a new perspective, by Magni C.A. (February 2010)

20 The skew pattern of implied volatility in the DAX index options market, by Muzzioli S. (December 2009)

19 Accounting and economic measures: An integrated theory of capital budgeting, by Magni C.A. (December 2009)

18 Exclusions of US-holders in cross-border takeover bids and the principle of equality in tender offers, by Mucciarelli F. (May 2009).

17 Models for household portfolios and life-cycle allocations in the presence of labour income and longevity risk, by Torricelli C. (March 2009)

16 Differential evolution of combinatorial search for constrained index tracking, by Paterlini S, Krink T, Mittnik S. (March 2009)

15 Optimization heuristics for determining internal rating grading scales, by Paterlini S, Lyraa M, Pahaa J, Winker P. (March 2009) 
14 The impact of bank concentration on financial distress: the case of the European banking system, by Fiordelisi F, Cipollini A. (February 2009)

13 Financial crisis and new dimensions of liquidity risk: rethinking prudential regulation and supervision, by Landi A, Gualandri E, Venturelli V. (January 2009)

12 Lending interest rate pass-through in the euro area: a data-driven tale, by Marotta G. (October 2008)

11 Option based forecast of volatility: an empirical study in the Dax index options market, Muzzioli S. (May 2008)

10 Lending interest rate pass-through in the euro area, by Marotta G. (March 2008)

9 Indebtedness, macroeconomic conditions and banks' losses: evidence from Italy, by Torricelli C, Castellani S, Pederzoli C. (January 2008)

8 Is public information really public? The role of newspapers, Ferretti R, Pattarin F. (January 2008)

7 Differential evolution of multi-objective portfolio optimization, by Paterlini S, Krink T. (January 2008)

6 Assessing and measuring the equity gap and the equity, by Gualandri E, Venturelli V. (January 2008)

5 Model risk e tecniche per il controllo dei market parameter, Torricelli C, Bonollo M, Morandi D, Pederzoli C. (October 2007)

4 The relations between implied and realised volatility, are call options more informative than put options? Evidence from the Dax index options market, by Muzzioli S. (October 2007)

3 The maximum LG-likelihood method: an application to extreme quantile estimation in finance, by Ferrari D., Paterlini S. (June 2007)

2 Default risk: Poisson mixture and the business cycle, by Pederzoli C. (June 2007)

1 Population ageing, household portfolios and financial asset returns: a survey of the literature, by Brunetti M. (May 2007) 